\title{
Functionalized Mesoporous Silicon Nanomaterials in Inorganic Soil Pollution Research: Opportunities for Soil Protection and Advanced Chemical Imaging
}

\author{
Jia-Wei Yang ${ }^{1} \cdot$ Wen Fang ${ }^{2} \cdot$ Paul N. Williams ${ }^{1}$ (D) John W. McGrath ${ }^{1} \cdot$ Carlos Eduardo Eismann $^{3} \cdot$ \\ Amauri Antonio Menegário ${ }^{3}$. Lucas Pellegrini Elias ${ }^{3}$ Jun Luo $^{2} \cdot$ Yingjian Xu $^{4,5}$
}

Published online: 1 July 2020

(C) The Author(s) 2020

\begin{abstract}
"Innovative actions towards a pollution free-planet" is a goal of the United Nations Environment Assembly (UNEA). Aided by both the Food and Agricultural Organisation (FAO) and its Global Soil Partnership under the 3rd UNEA resolution, a consensus from $>170$ countries have agreed a need for accelerated action and collaboration to combat soil pollution. This initiative has been tasked to find new and improved solutions to prevent and reduce soil pollution, and it is in this context that this review provides an updated perspective on an emerging technology platform that has already provided demonstrable utility for measurement, mapping, and monitoring of toxic trace elements (TTEs) in soils, in addition to the entrapment, removal, and remediation of pollutant sources. In this article, the development and characteristics of functionalized mesoporous silica nanomaterials (FMSN) will be discussed and compared with other common metal scavenging materials. The chemistries of the common functionalizations will be reviewed, in addition to providing an outlook on some of the future directions/applications of FMSN. The use of FMSN in soil will be considered with some specific case studies focusing on $\mathrm{Hg}$ and As. Finally, the advantages and developments of FMSN in the widely used diffusive gradients-in-thin films (DGT) technique will be discussed, in particular, its advantages as a DGT substrate for integration with oxygen planar optodes in multilayer systems that provide 2D mapping of metal pollutant fluxes at submillimeter resolution, which can be used to measure detailed sediment-water fluxes as well as soil-root interactions, to predict plant uptake and bioavailability.
\end{abstract}

Keywords Functional mesoporous silicon nanomaterials (FMSN) $\cdot$ Diffusive gradient in thin films (DGT) $\cdot$ X-ray fluorescence spectrometry $(\mathrm{XRF}) \cdot$ Heavy metals $\cdot$ Soil pollution

This article is part of the Topical Collection on Land Pollution

Electronic supplementary material The online version of this article (https://doi.org/10.1007/s40726-020-00152-6) contains supplementary material, which is available to authorized users.

Paul N. Williams

p.williams@qub.ac.uk

$\triangle$ Amauri Antonio Menegário

amauri.antonio-menegario@unesp.br

Jun Luo

esluojun@nju.edu.cn

Yingjian Xu

Goldenkeys9996@thegoldenkeys.com.cn

1 Institute for Global Food Security, School of Biological Sciences, Queen's University Belfast, Belfast, Northern Ireland BT9 5DL, UK
2 State Key Laboratory of Pollution Control and Resource Reuse, School of the Environment, Nanjing University, Nanjing 210023, Jiangsu, China

3 Environmental Studies Center (CEA), São Paulo State University (UNESP), Avenida 24-A, 1515, Rio Claro, SP 13506-900, Brazil

4 Department of Chemistry, University of Warwick, Coventry CV4 7AL, UK

5 GoldenKeys High-Tech Materials Co., Ltd., Building B, Innovation \& Entrepreneurship Park, Guian New Area, Guian 550025, Guizhou, China 


\section{Introduction to FMSN}

\section{The Development of FMSN and Its Principles of Adsorption}

Functionalized mesoporous silica nanomaterials (FMSN) can be ordered by the physical/structural characteristics of the inert hosting material and/or the chemistries of the functionalization. Both factors control the behavior of the material and its suitability for different tasks and conditions. This ability for optimization and fine-tuning has made FMSN an increasingly promising technology for medical and environmental applications. The most popular configurations have a tendency for large pore volumes but variable pore sizes, high surface areas, and a stability that makes them reliable even in challenging matrixes (low $\mathrm{pH}$, high organic concentrations) and environmental conditions (low-high temperatures) [1-3]. The crystal state of FMSN is shown in Fig. 1. To develop a better understanding of FMSN, it is instructive to consider how they have developed, why, and the technologies that they have superseded.

Research on FMSN has been ongoing for ca. 30 years. In the early 1990s, the initial aim was to expand beyond the confines of zeolite minerals used for ion exchange and contaminant sorption. These hydrated aluminosilicates, comprising of a tetrahedra patchwork of alumina and silica structures, were the most widely used metal/elemental scavengers. Effective as they were, however, they had their limitations, and consequently, there was a demand for new materials (mesoporous silica) with more structured/controlled pores of sizes between 2 and $10 \mathrm{~nm}$. These designs were needed to accommodate molecules that could not be captured by existing zeolites because they were not small enough to fit in the micropores [4]. It was not until 1992 that the first scanning electron microscopy (SEM) micrograph of mesoporous silica appeared, yielding a greater appreciation of their detailed/ intricate structure and how synthesis conditions governed morphogenesis [5]. In 1998, Stucky and colleagues synthesized mesoporous silica with larger pores $(30 \mathrm{~nm})$, further expanding the range of molecules accessible to the interiors of the Si crystals [6] and opening up new opportunities for functionalization.

It is also worth noting that FMSN have benefited from the increase of interest in nanotechnologies. In accordance with the International Organization for Standardization definition
Fig. 1 Copper removal by iMoLboX FMSN and its high absorbing capacity. a Partitioning of $\mathrm{Cu}$ from $15 \mathrm{ml} 98 \%$ anhydrous ethanol solution ( $\mathrm{pH} 4-6)$ containing $30 \mathrm{mg} \mathrm{L}^{-1} \mathrm{CuSO}_{4}$ into 0.025 g FMSN, removal efficiency reached $92.97 \%$. The color change of the solution is caused by bromophenol blue $(0.1-0.3 \mathrm{ml})$. The color of FMSN changed from colorless to blue after the adsorption was completed. b Si crystal image before and after palladium recovery from a solution $(\mathrm{pH} 2-5)$ of $250 \mathrm{mg} \mathrm{L}^{-1} \mathrm{PbCl}_{2}$. c and d Si dosed with $30 \mathrm{mg} \mathrm{L}^{-1} \mathrm{CuSO}_{4}$ solution (pH 4-6). e Si crystal image before and after iron recovery from a solution $(\mathrm{pH} 3-5)$ of $150 \mathrm{mg} \mathrm{L}{ }^{-1} \mathrm{FeCl}_{3} / \mathrm{FeCl}_{2}$. Si crystal particle size is $180-600$ microns. The images of FMSN particle were obtained through compound optical microscope (LEICA DM500), provided by GoldenKeys High-tech Materials Co., Ltd. a
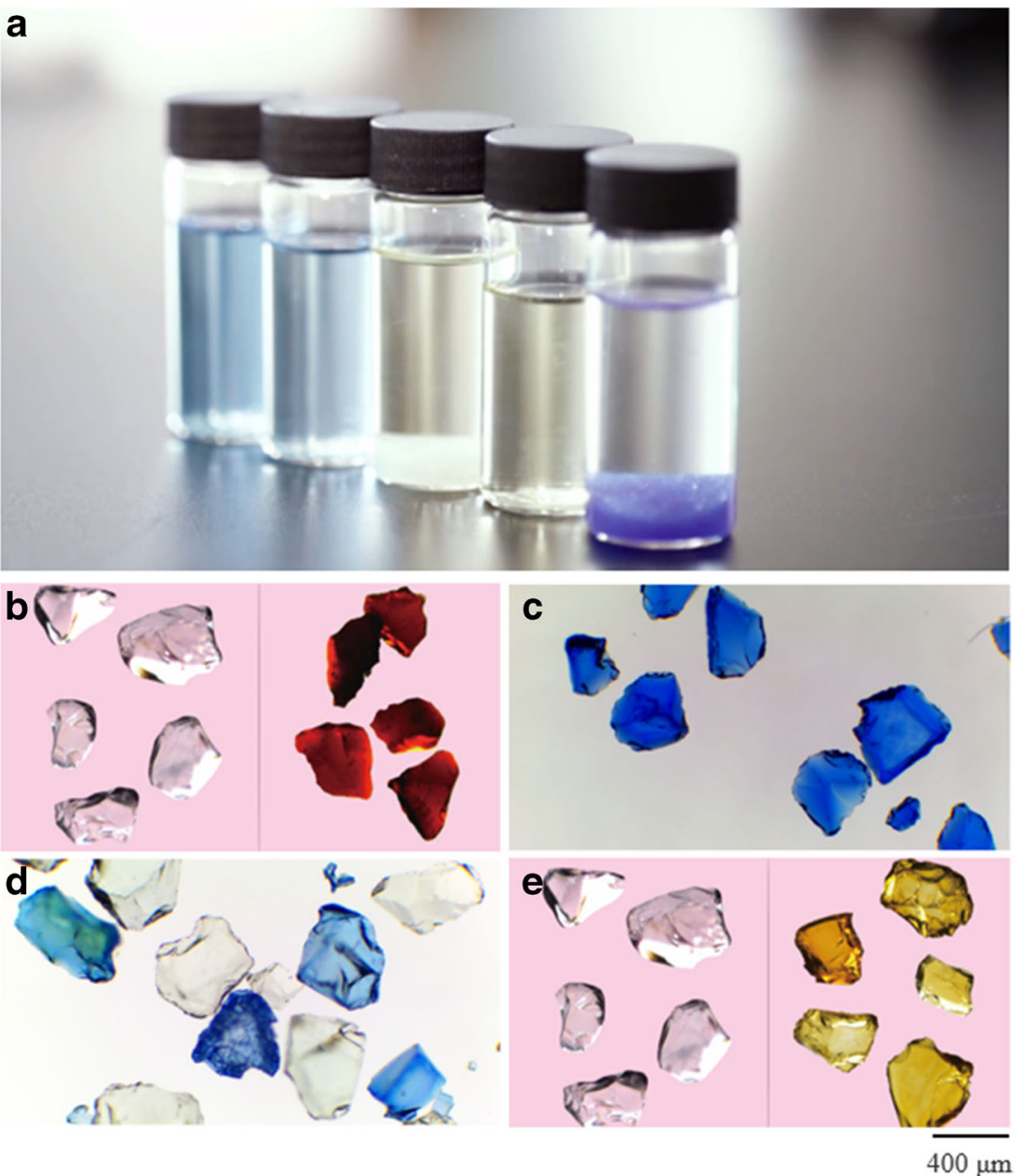
in ISO/TS 80004, nanomaterials encompass not just materials with any external dimension between 1 and $100 \mathrm{~nm}$ but those "having internal structure or surface structure in the nanoscale" [7]. With the development of nanomaterials, researchers have discovered the potential of functionalized silica as an advanced chemical material $[8,9]$. Combining an ease of surface modification and synthesis, good biocompatibility and stability FMSN quickly became a viable replacement/ alternative to zeolites [10].

The other metal-removing agent traditionally used is activated carbon (AC). It has been successfully used in many industrial applications. AC has been applied successfully before to remove $\mathrm{As}, \mathrm{Cr}$, and pharmaceutical compounds from water [11-13]. It is also applied for greenhouse gas capture [14], electrical energy applications (as an ultra-capacitor) [15-17], and as an air pollution mitigator [18, 19].

The adsorption capacity traits associated with AC depend principally on their porosity and surface area [20]. Two traditional methods are used to prepare $\mathrm{AC}$ that delineate by either physical or chemical activation. Physical activation involves carbonization of organic matter, and then, the resulting char is modified in the presence of an activator (such as $\mathrm{CO}_{2}$ or steam). In chemical activation, the activating agents (such as $\mathrm{K}_{2} \mathrm{CO}_{3}$ ) is used directly for raw material impregnation. Next, heat treatment is applied in an inert atmosphere (various/high temperatures) [20]. Generally, compared with physically activated $\mathrm{AC}$, chemically activated $\mathrm{AC}$ has a larger surface area and a smaller pore size, with a wider range of applications [21].

Activated carbon in general has a high internal surface area due to its special sponge-like structure. Moreover, these adsorbents have reasonable chemical stability [22]. Suitable natural ingredients are continually being sought to make low-cost $\mathrm{AC}$ materials. To date, $\mathrm{AC}$ has been formed successfully from agricultural wastes as diverse as apricot and bagasse, grape seeds and cherry stones, rice husks, coconut, tomato processing solid waste, etc. [12], which highlights its versatility.

The main benefit associated with $\mathrm{AC}$ as a clean-up technology for use in wastewater is its overall chemical flexibility and universality. This stems from its large specific surface area, adsorption capacity, wetting characteristics, and heterogeneous porous structure; all of this can be tailored via regulation of the physical/chemical activation steps [23]. The general adsorption capacity of $\mathrm{AC}$ depends principally on physical entrainment and then secondly by chemical properties. However, for metal adsorption specifically, the surface chemistry and configuration of outer ligands on the $\mathrm{AC}$ are of more importance, providing some element/species selectivity [24, $25]$. The problem, though, is that the distribution of functional groups can also change the structure of the $\mathrm{AC}[24,25]$. This complicates attempts to further functionalize the char, as chemical changes can similarly cause physical modification, with potentially behavior-altering changes for the metal scavenger. Ideally, an inert/stable host is required for functionalization, as this enables better control of the specific chemistries, which is the key to superior performance. Functionalized Si meets these requirements, and this has been partly the catalyst for the rapid development of FMSN.

Many popular metal clean-up methods rely on materials that utilize ion exchange as the main binding mechanism. Here, the process centers on the exchange of ions between a solid and an associated liquid phase [26]. The solid phase is called the ion exchange resin/ion exchanger, because it carries exchangeable ions, insoluble in the liquid phase and during chemical reactions/interactions maintains its structural integrity [27]. The most useful ion exchangers are reversible enabling the materials to be reused multiple times, and based on the charge characteristics of the ion reactions, the materials can be further defined as either cation or anion exchangers [27]. High-quality ion exchangers should have chemical and physical stability, large surface areas, and large ion exchange capacities, and exhibit a relatively fast ion exchange speed [28].

FMSN structural/chemical attributes make them highly attractive to be configured as ion exchangers. However, specialist ion exchange membranes remain the most popular and widely used technology platform for ion exchange-mediated metal removal. This is despite many studies having shown that membrane-based ion exchangers have numerous practical limitations. The most significant of these being poor chemical stability in alkaline environments [29]. For example, in matrixes with a high $\mathrm{pH}$, hydrogen peroxide (including its free radicals) is particularly reactive/damaging for ion exchange membrane modules, making them prone to premature failure $[29,30]$. An exception to this is perfluorinated anion exchange membranes, which have outstanding proton conductivity and chemical stability, but suffer from high production costs and a low ion selectivity [30]. In addition, the degradation treatment of waste after the use of ion exchange membranes is still very complicated [31]. As although the elemental target is removed from the matrix, the counter ion still replaces it and this can cause new/secondary problems. In contrast, functional silicas have a more stable chemistry and are less expensive to manufacture. There is also no requirement for a chemical "swap" or exchange to occur, which improves the quality of the treated liquid phase. It is these practical considerations with ion exchange membranes being generally limited by relatively high capital and operating costs, as well as technical or economic constraints [32], that have seen many industries moving away from these systems. Functionalised silica on the other hand have a low operating cost and can be optimized to work in environments with high dissolved organic carbon and low $\mathrm{pH}$ [33].

This major increase in the popularity of FMSN research is exemplified by two FMSN in particular: Mobile Crystal Corporation (MCM-41) and Santa Barbara Amorphous 
(SBA-15). These two categories of mesoporous silica have received the most attention. Figure 2 shows that the number of FMSN studies published started to increase rapidly from the early 2000s onwards. Today, there are over 70,000 published papers featuring SBA- 15 and MCM-41.

The majority of FMSN studies over the last two decades have focused on the synthesis and preparation of new materials [34-39]. During this period, there has been a constant development of novel structures and functionalizations, with major gains in the understanding of the importance of the inner fine structure of mesoporus $\mathrm{Si}$ along with the mechanisms of FMSN binding [40-42]. Depending on the pore length/size, the mass transfer and rate of molecular diffusion are modulated [43, 44]. However, the pore sizes do not need to be uniform through the Si either, and this creates additional scope for tailoring the chemistries for a specific environment or need. For example, Peng et al. [45] were able to create specific mesopore channel regions within the $\mathrm{Si}$ with larger surface areas and pore diameters $(3.0$ to $7.3 \mathrm{~nm}$ ) by adding 1,3,5-trimethyl benzene alongside cetyltrimethyl ammonium bromide (CTAB) during synthesis. This tuneable micelle core-swelling agent provided a template that controlled the shell architecture of the internal cavities, one that could be easily removed from the silica structure prior to use. It was this manipulation that created the $2 \mathrm{D}$ hexagonal mesostructure, with smaller pores in the shell and larger spaces in the silica core, providing the material with its unique, 2-step adsorption-desorption characteristics [45].

However, despite the increasing role and complexity of mesoporous structure as a determinant of adsorption behavior, it is still the functionalization process that dominates the materials' final characteristics. Thus, introducing different functional groups ultimately controls the metal ions' adsorption both externally and internally within the adsorbent. For example, carboxylate, sulfonate, and phosphate groups promote the adsorption of metal ions through ion exchange, while amine moieties typically operate by complexation. The adsorption of metals by FMSN in water is mainly based on the use of surface-grafted functional groups, such as amino or mercapto, for complex coordination, thereby achieving selective adsorption of metal ions [46]. Studies have also shown that the adsorption capacity of FMSN increases with an increase in the total concentration of functional groups. The surface area of the adsorbent is obviously an important factor determining functional group concentration [47]. However, the branching structures of the functionalizations, and how many terminal groups there are, also play a defining role.

For the adsorption of nonionic organic matter in water, generally, grafting alkanes onto the FMSN increases surface hydrophobicity, which is beneficial to the capture of organic matter. For the adsorption of ionic organics, the charge density of the solid surface is the key factor for adsorption. The degree of interaction between ionic organics and FMSN changes due to variation in solution $\mathrm{pH}$, because the surface charge of the FMSN and the ionic radius of the ion target are controlled by $\mathrm{pH}$. The ionic strength and ionic composition of the solution also affect the adsorption of ionic organics, especially when inorganic ions compete with organic ions for binding sites [46]. With greater appreciation of the unique adsorbing ability of functional silica, this has prompted more studies to consider a broader range of chemical targets, further expanding the utility of FMSN [48-50]. For example, there are specialist FMSN scavengers for both $\mathrm{Hg}[51]$ and $\mathrm{Cu}[52,53]$. Despite the vast number of wastewater treatment and environmental protection technologies available, FMSN have proven themselves to be a sector leader for metal-chemical removal [54].
Fig. 2 The cumulative number of published papers featuring SBA15 and MCM-41 FMSN (Data source: Scopus)

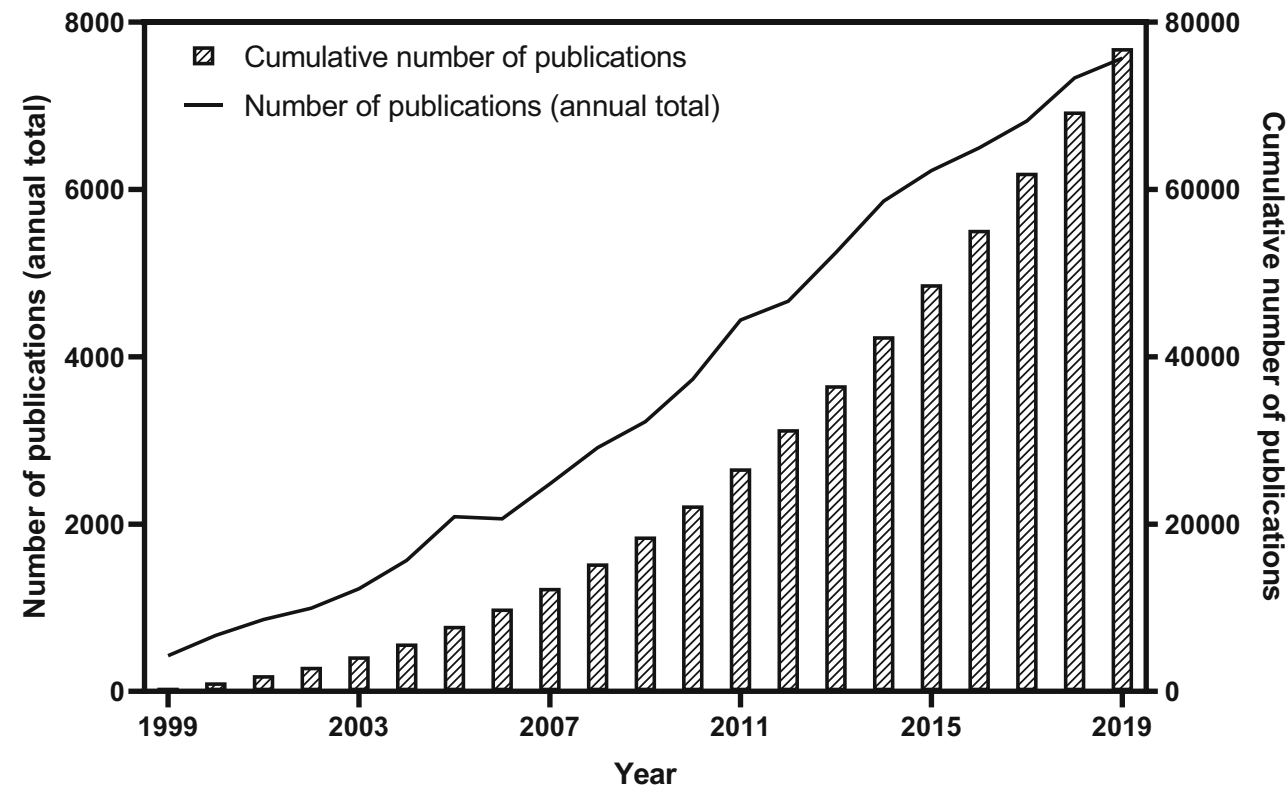




\section{Synthesis of FMSN}

There are three main steps in the production of FMSN, synthesis, surface modification, and stabilization. The synthesis of mesoporous silica is commonly performed by base or acid hydrolysis, using an alkoxysilane precursor. The ordered architecture of pores and channels is obtained from amphiphilic micelles which are trapped under the silica network. This template/mold is then removed by either chemical extraction or heat-assisted treatments. The pore length and diameter can be adjusted by altering the amount and type of templating agent used and the reaction conditions [10]. Protective etching with $\mathrm{NaOH}$ on silica coated with PVP molecules can be used to form FMSN, especially for crystalline silica such as quartz, cristobalite, and tridymite [55]. Variation in the hollow silica channels is achieved with different etching speeds and durations, and the targeting of outer or interior regions of the particle. However, fine control of pore structure is difficult, with this method approach being more suited to disordered mesopore synthesis [56].

Post-synthesis surface modification and direct synthesis (onestep synthesis/co-condensation) methods are applied to fix organic functionalities to mesoporous silica [57]. For example, in the post-synthesis surface modification of reactive nano-silica, sodium silicate undergoes a hydrolysis reaction as $\mathrm{pH}$ decreases. This then generates $\mathrm{Si}(\mathrm{OH})_{4}$ monomers which are then developed through a series of dehydration condensation reactions, resulting in a high-density surface functionalization with active hydroxyl groups. At the same time, methoxyl groups of the surface modifier 3-mercaptopropyl-trimethoxysilane (MPTS) then hydrolyze under alkaline conditions to produce the active surhydroxyl group. These active hydroxyl groups generated by MPTS then react with the surface functionalized hydroxyl groups just generated on the silica, forming Si-O-Si bonds and thus providing the mesoporous silica with surface adhered sulfhydryl groups [58].

Through the co-condensation of precursor inorganic framework materials with terminal trialkoxyorganosilanes (such as $\left.\left(\mathrm{R}^{\prime} \mathrm{O}\right)_{3} \mathrm{SiR}\right)$, the mesoporous silica phase can be prepared. This results in organic moieties being covalently anchored to the pore/channel walls of the silica in an orientation that enables them to project directly into the pore walls [57]. The advantage to this functionalization approach is that obstructions within the pores themselves caused by the organic units are minimized. An additional merit is that the modifications are more homogenously distributed within the pores, compared with other techniques. However, the degree of mesoscopic order of the FMSN needs to be monitored. As the ratio between the organic and silica increases in the reaction mixture, a more disordered and less reproducible material is produced [57]. These restrictions though can be conquered with the inclusion of structure-directing agents, producing a class of materials termed periodic mesoporous organosilicas (PMOs). Here, the functionalizations are integral components of the silica structure, resulting in a narrow pore radius distribution and well-organized pore network [57].

The final production stage of FMSN is stabilization. Here, functionalization can be used to give different regions within the Si particle different properties. For example, the core can be made hydrophobic and the shell hydrophilic [59]. This is a key part in improving hydrothermal stability. Hydrophobicity enhances the hydrothermal stability of materials in the aqueous environment, and hydrophilicity ensures biocompatibility. The free silanol $(\mathrm{Si}-\mathrm{OH})$ groups on the materials can provide a certain degree of hydrophilicity; with the help of condensers, these will be further used to modify some functional groups, biomolecules, or drug molecules $[60,61]$.

\section{Diversity of FMSN's Functional Groups}

Many studies have reported that FMSN with different functional groups have specific selective adsorption functions. In Georgescu's study [62], synthesized FMSN (TACfunctionalized silica) used for the removal cadmium and copper from water, adsorption results show that $0.1 \mathrm{~g}$ of FMSN can extract $94 \%$ of $\mathrm{Cd}$ (II) and $98 \%$ of $\mathrm{Cu}$ (II) from aqueous solutions ( $\mathrm{pH} \mathrm{6).} \mathrm{Li} \mathrm{et} \mathrm{al.} \mathrm{[33],} \mathrm{through} \mathrm{a} \mathrm{one-step} \mathrm{method,}$ synthesized LMS-AP-FMSN. In a subsequent wastewater treatment experiment, LMS-AP has good metal removal efficiency, and the removal rate of $\mathrm{Al}, \mathrm{Pb}$, and $\mathrm{Zn}$ reached more than $80 \%$. But the adsorption of $\mathrm{Cr}$ from the same waste water was only ca. $70 \%$, while the removal of As was less still at only $30-40 \%$ [33]. The huge variety of mesoporous structures, pore network structures, combined with functionalization configurations makes FMSN a highly versatile yet extremely powerful chemical solution to toxic element containment. However, with the enormity of different FMSN configurations, selecting the right materials for the correct conditions is still challenging, and their effectiveness requires case-by-case validation. In the following sections, the application of FMSN in tackling environmental pollution will be discussed.

\section{Current Applications and Future Directions of FMSN}

\section{The Use of FMSN in Water and Food Security}

FMSN are currently widely used to absorb numerous metal ions and compounds from aqueous solutions [63-66] (Table 1). For example, Xia et al. [63] synthesized a variety of different FMSN to study comparatively, FMSN adsorption capacity for TTEs in water. In their absorption experiments, $\mathrm{Cd}(\mathrm{II}), \mathrm{Mn}(\mathrm{II}), \mathrm{Pb}(\mathrm{II})$, and $\mathrm{Fe}(\mathrm{III})$ concentrations were all $0.5 \mathrm{mg} \mathrm{L}^{-1}$ in drinking water with a $\mathrm{pH}$ of $\sim 4$; it was found among the types of FMSN tested; S16-1N completely removed these four elemental impurities $(<$ detection limit). 
Table 1 A summary of FMSN applications used to remove metals and compounds from waters

\begin{tabular}{|c|c|c|c|c|}
\hline MFS & Species & $\begin{array}{l}\text { Dominant system/ } \\
\text { scheme }\end{array}$ & Key finding & Ref. \\
\hline SBA-15 & $\mathrm{Cu}(\mathrm{II})$ and $\mathrm{Cd}$ (II) & $\begin{array}{l}\text { The adsorption of } \\
\text { copper and cadmium } \\
\text { ions was studied }\end{array}$ & $\begin{array}{l}\text { The adsorption capacity of SBA- } 15 \text { for } \\
\mathrm{Cu} \text { (II) and } \mathrm{Cd} \text { (II) in a single metal } \\
\text { solution was determined and related } \\
\text { to the density and structure of the } \\
\text { organic groups grafted on the surface } \\
\text { of SBA-15. }\end{array}$ & Georgescu et al. [62] \\
\hline SBA-15 & $\mathrm{Pb}$ (II) and $\mathrm{Cu}(\mathrm{II})$ & Adsorption experiment & $\begin{array}{l}\text { The adsorption of thiol-group SBA-15 } \\
\text { and The amino-group SBA-15 to } \\
\mathrm{Cu}(\mathrm{II}) \text { and } \mathrm{Pb} \text { (II) was studied. }\end{array}$ & Lee et al. [67] \\
\hline SBA-15 & $\mathrm{U}(\mathrm{VI})$ & Adsorption experiment & $\begin{array}{l}\text { SBA-15-PA showed not only a good } \\
\text { sorption ability and a desirable } \\
\text { selectivity for U(VI) over a range of } \\
\text { competing metal ions but also an } \\
\text { excellent reusability. }\end{array}$ & Wang et al. [68] \\
\hline $\begin{array}{l}\text { Porous silica materials } \\
\text { S8, S12, S16, and } \\
\text { SBA }\end{array}$ & $\begin{array}{l}\mathrm{Cd}(\mathrm{II}), \mathrm{Pb}(\mathrm{II}), \\
\quad \mathrm{Fe}(\mathrm{III}), \mathrm{Mn}(\mathrm{II})\end{array}$ & $\begin{array}{l}\text { Heavy metal adsorption } \\
\text { experiments }\end{array}$ & $\begin{array}{l}\text { Monoamino-functionalized silica } \\
\text { S16-1N shows effectively remove } \\
\text { heavy metal } \mathrm{Cd}(\mathrm{II}), \mathrm{Pb}(\mathrm{II}), \mathrm{Fe}(\mathrm{III}) \text {, } \\
\text { and } \mathrm{Mn}(\mathrm{II}) \text {. }\end{array}$ & Xia et al. [63] \\
\hline $\begin{array}{l}\text { Mesoporous silicas } \\
\text { MCM-41 and } \\
\text { MSU-H }\end{array}$ & $\begin{array}{l}\text { Hydrogen } \\
\text { peroxide }\end{array}$ & $\begin{array}{l}\text { Hydrogen peroxide } \\
\text { adsorption analysis }\end{array}$ & $\begin{array}{l}\text { MSU-H silica have better absorption } \\
\text { ability than MCM-41 because its } \\
\text { lager pore size. }\end{array}$ & $\begin{array}{c}\text { Lewandowski } \\
\text { et al. [64] }\end{array}$ \\
\hline LMS-AP & $\mathrm{Pb}$ (II) & $\begin{array}{l}\mathrm{Pb}(\mathrm{II}) \text { adsorption } \\
\text { experiments }\end{array}$ & $\begin{array}{l}\text { In actual industrial wastewater } \\
\text { treatment process, LMS-AP had a } \\
\text { better } \mathrm{Pb}(\mathrm{II}), \mathrm{Zn}(\mathrm{II}) \text {, and } \mathrm{Cr}(\mathrm{VI}) \\
\text { removal efficiency of } 80 \% \text { and As } \\
\text { (V) of } 30-40 \% \text { removal efficiency at } \\
\text { initial } \mathrm{pH} 4 \text {. }\end{array}$ & Li et al. [33] \\
\hline $\begin{array}{r}\mathrm{Fe}_{3} \mathrm{O}_{4} @ \mathrm{SiO}_{2} \\
-\mathrm{NH}_{2} \& \mathrm{~F} 13\end{array}$ & $\begin{array}{l}\text { Perfluorinated } \\
\text { compounds } \\
\text { (PFC) }\end{array}$ & Sorption experiment & $\begin{array}{l}\text { For the removal of PFC from surface } \\
\text { water samples, Fe3O4 @ } \mathrm{SiO} 2 \\
\text {-NH2\&F13 has a good } \\
\text { anti-interference ability, and shows } \\
\text { good removal efficiency ( } 86.29 \%) \\
\text { for the nine PFCs analyzed in this } \\
\text { study, as well as its reusability and } \\
\text { stability. }\end{array}$ & Zhou et al. [65] \\
\hline SiO2@AZOL & $\begin{array}{l}\mathrm{Hg}(\mathrm{II}), \mathrm{Cd}(\mathrm{II}) \\
\quad \mathrm{Cu}(\mathrm{II}), \text { and } \\
\mathrm{Zn}(\mathrm{II})\end{array}$ & Adsorption studies & $\begin{array}{l}\text { The material shows a high adsorption } \\
\text { capacity for a variety of toxic metal } \\
\text { ions }(\mathrm{Hg}(\mathrm{II}), \mathrm{Cd}(\mathrm{II}), \mathrm{Cu}(\mathrm{II}) \text {, and } \\
\mathrm{Zn}(\mathrm{II})) \text {. }\end{array}$ & Chatterjee et al. [66] \\
\hline
\end{tabular}

The excellent performance of S16-1N can be ascribed to its high pore volume and specific surface area, along with possessing high accessibility to its functional group ligands [63]. Chatterjee et al. [66], by using a modified Stober process, synthesized cubic mesoporous silica, then it was functionalized to produce a fluorogenic silica probe material $\left(\mathrm{SiO}_{2} @ \mathrm{AZOL}\right)$. The adsorption experiment of the fluorogenic silica probe material was performed in a solution with a $\mathrm{pH}$ of ca. 7. It was found that this material showed an extraction efficiency of around $99 \%$ for $\mathrm{HSO}_{3}{ }^{-}, \mathrm{Cd}(\mathrm{II})$, $\mathrm{Hg}(\mathrm{II}), \mathrm{Zn}(\mathrm{II})$, and $\mathrm{Cu}(\mathrm{II})$, with adsorption capacities of 873 , $633,630,412$, and $260 \mathrm{mg} \mathrm{g}^{-1}$, respectively [66]. For existing industrial applications, in Guizhou, China, the FMSN iMoLboX has been successfully applied to retrieve precious metals in addition to the removal of TTEs from a variety of process waste streams. For example, iMoLboX has achieved a 96.14\% removal efficiency of As in medium/ strong acid solution (mass fraction of $65-85 \%$ ) containing $300 \mu \mathrm{g} \mathrm{L}^{-1}$ As. While it possesses a removal efficiency for $\mathrm{Cu}$ of $92.97 \%$ in aqueous solutions containing $30 \mathrm{mg} \mathrm{L}^{-1}$ $\mathrm{CuSO}_{4}$ (Fig. 1). In addition, iMoLboX FMSN can effectively extract $\mathrm{Rh}$ from acidic aqueous solutions containing $57 \mathrm{mg}$ $\mathrm{L}^{-1} \mathrm{Rh}(\mathrm{III})$, and remove Pd from organic alcohol solutions containing $562 \mathrm{mg} \mathrm{L}^{-1} \mathrm{Pd}(\mathrm{II})$; in both cases, removal efficiency is $>99 \%$ [69]. But the adsorption efficiency of ion exchange resins for $\mathrm{Rh}(\mathrm{III})$ and $\mathrm{Pd}(\mathrm{II})$ from $8.9 \mathrm{mg} \mathrm{L}^{-1}$ $\mathrm{Rh}$ (III) solution and $43.9 \mathrm{mg} \mathrm{L}^{-1} \mathrm{Pd}(\mathrm{II})$ solution is only about $90 \%$ [70], while the removal ratio of $\mathrm{AC}$ for $\mathrm{Pd}(\mathrm{II})$ from $100 \mathrm{mg} \mathrm{L}^{-1} \mathrm{Pd}(\mathrm{II})$ solution is $93.5 \%$ [71].

Fluorine is highly reactive and forms a great variety of chemical compounds. It is used extensively in the nuclear and metal processing industries, in electronics, as a surfactant, 
features prominently in polymers and in agrochemicals where it features within pesticide formulations. Fluorinated compounds though are major environmental pollutants and can be difficult to remove from waters. Zhou et al. [65] developed a novel silica functionalized nanocomposite $\left(\mathrm{Fe}_{3} \mathrm{O}_{4} @ \mathrm{SiO}_{2^{-}}\right.$ $\mathrm{NH}_{2} \& \mathrm{~F}_{13}$ ); this material showed a good selectivity for perfluorinated compounds (PFCs). In a 1-L water sample fortified with PFC concentrations ranging from 0.5 to $50 \mathrm{ng} \mathrm{L}^{-1}$, the composite possessed a much better removal efficiency (86.29\%) for PFCs than that (58.61\%) of powdered AC [65].

FMSN can also be used to extract drug residues from food [72]. In this example, three different mesostructured silicas (SBA-15-C18, MSU-2-C18, HMS-C18) with added octadecylsilane groups were trialed. Despite the functionalization approach being identical, the different silica structures evolved distinctive binding properties. SBA-15C18 was the least effective scavenger due to hydrophobic and polar secondary/hydrogen bonding interactions caused from the functionalization leaving a high frequency of nonmodified silanol groups in the silica. However, HMS-C18 proved a promising multi-drug sorbent. Out of the panel of 26 veterinary drug residuals tested from bovine meat samples, the extraction efficiency for more than half of these compounds was over $80 \%$ [72]. Although the direct use of FMSN in food safety is new, the successes to date provide further evidence of the materials' wide-ranging applications, across diverse chemical conditions. However, perhaps, it is the use of FMSN to combat soil pollution that might be the materials' greatest contribution to our future food safety [73].

\section{The Use of FMSN in Soil Research}

FMSN has good compatibility for use within soil because it is inert, highly stable, and soils naturally already contain high proportions of silica. The application of FMSN in soil research is a theme that has only emerged relatively recently. The two principle directions being soil remediation (direct amendment) [73] and in situ measurement [74].

Although the use of functionalized silica in soils is relatively new, there have already been a number of successful applications. For example, diacetylmonoxime-functionalized silica gel has been used to remove $\mathrm{Cu}$ from fly ash-ameliorated soil samples [75]. In this study through FTIR, element analysis, BET surface area analysis, and ${ }^{13} \mathrm{C}$ CPMAS NMR spectroscopy, it was shown that the FMSN have high selectively for $\mathrm{Cu}$ removal with a preconcentration factor of 250; sorption capacity reached $0.93 \mathrm{mmol} \mathrm{g}^{-1}$. Kinetic parameters and isotherms correlated well with the pseudo-second-order and Langmuir models [75]. Another important study reported that FMSN can limit the absorption of toxic metals and As by plants through reducing bioavailability. In this example, a soil with an As concentration of $9.87 \pm 1.22 \mathrm{mg} \mathrm{kg}^{-1}$ had the fraction of unavailable As increased from 40 to $77 \%$ after
FMSN was applied [76]. Similarly, Lian et al. [58] used FMSN in contaminated soil to selectively immobilize $\mathrm{Pb}$ and Cd. Results showed that the FMSN applications can decrease the pools of bioavailable $\mathrm{Cd}$ and $\mathrm{Pb}$ from $12 \mathrm{mg} \mathrm{kg}^{-1}$ and $1194 \mathrm{mg} \mathrm{kg}^{-1}$ to $0.2 \mathrm{mg} \mathrm{kg}^{-1}$ and $10 \mathrm{mg} \mathrm{kg}^{-1}$, respectively, with the immobilization efficiency of $\mathrm{Pb}$ and $\mathrm{Cd}$ reaching $99.12 \%$ and $98.23 \%$. More importantly, this FMSN exhibited a low effect on other soil parameters. While the $\mathrm{Cd}$ and $\mathrm{Pb}$ species immobilized by FMSN exhibited greatly increased acid resistance [58], an attribute making FMSN suited for long-term remediation roles.

Recently, a series of studies has shown that FMSN can be used for remediating Cd-contaminated agriculture soil [73, 77]. The stabilization efficiency of Cd by FMSN reached up to $91.2 \%$ with just a $1 \%$ application. At the same time, the migration rate of $\mathrm{Cd}$ in the soil decreased from 45.8 to $19.0 \%$, and the effect of the addition of FMSN on the soil properties was negligible [77]. In addition, FMSN reduced the leaching rate of $\mathrm{Cd}$ in the soil (36.0\%) and bioavailability (54.3\%); the concentration of $\mathrm{Cd}$ in crops decreased more than 50\% [73].

Directly, addressing pollutant bioavailability with amendments is one solution to improve soil health. However, any implementation of such technologies needs sufficient knowledge of in situ conditions and subsequent pollutant mobility. Over the past couple of decades, the passive sampling technology of DGT has emerged as a leading method for the measurement of bioavailability for inorganic and organic contaminants in soil. However, the connection with FMSN is that they are increasingly being used as DGT substrates, opening up a range of exciting avenues in soil testing, new rapid analysis approaches, and for high-resolution 2D ion-mapping of pore water chemistries.

\section{The Use of FMSN in DGT Research}

\section{DGT Introduction}

DGT was originally developed for aquatic systems, then evolved into an established technique to understand chemical lability and speciation in soil [78]. Comprising of a base unit, a cap, and thin film stack system (consisting of a membrane filter, diffusive gel, and binding layer), the DGT configuration is robust, easy to work with in the environment, and crucially, units do not require individual calibration [78]. The binding layer provides the device's selectively, while the diffusive layer controls solute transport and defines the intensity of the metal flux induced by the DGT device. Together, they both determine the measurement characteristics of a specific/individual DGT configuration.

In practice, DGT devices are easy to deploy in water/ sediment/soil; for a detailed review of the technique, refer to Davison [78]. After the DGT binding layer is recovered and eluted, quantitative analysis of the eluents can be 
achieved through a range of commonly available analytical techniques, including inductively coupled plasma mass spectrometry (ICP-MS), inductively coupled plasma optical emission spectrometry (ICP-OES), atomic absorption spectroscopy (AAS), and X-ray fluorescence (XRF). Environmental samples are prone to a wide range of measurement interferences due to matrix complexity. A further benefit of the DGT approach is that there is a preconcentration of the target analyte. In the following sections, the use of DGT and FMSN for the measurement of TTEs in soil will be discussed from the perspective of $\mathrm{Hg}$ and As pollution.

\section{Hg In Situ Sampling by DGT}

Mercury ( $\mathrm{Hg}$ ) pollution remains a key pollution focus, not only is it a potent human poison, but it can cause widespread environmental damage $[16,17]$. Mercury exposure can arise naturally from rock weathering, volcanic activity, and geological deposition [79]. However, the main sources of $\mathrm{Hg}$ release are from human activities, particularly waste incinerators, residential coal for heating and cooking, coalfired power plants, and mining for gold and other metals $[16,17,79,80]$. The fate and behavior of $\mathrm{Hg}$ are difficult to predict, which complicates the assessment of toxicological risk, due to the wide range of species and complexes found in the environment. Elemental mercury $(\mathrm{Hg} 0)$, referred to as quick silver, is the most volatile species, forming vapor easily at typical ambient temperature/pressure [81]. $\mathrm{Hg}(\mathrm{OH})_{2}, \mathrm{Hg}(\mathrm{OH}) \mathrm{Cl}$, and $\mathrm{HgCl}_{2}$ are common inorganic mercury $(\mathrm{iHg}$ ) compounds in freshwaters. However, because the $\mathrm{Cl}$ concentration in seawaters is higher, $\mathrm{Hg}$ speciation trends are also typified by $\mathrm{HgCl}^{+}, \mathrm{HgCl}_{2}, \mathrm{HgCl}_{3}{ }^{-}$, and $\mathrm{HgCl}_{4}{ }^{2-}$. Methylmercury $(\mathrm{MeHg})$ is an organometallic $\mathrm{Hg}$ species, characterized by extreme toxicity, making it the critical contaminant/pollutant in the environment [81].

Soil is an important reservoir of anthropogenic $\mathrm{Hg}$ release, playing a key role in the Hg cycle [82]. The soil environment is a heterogenous micro-landscape of solidsolution-gas interfaces, and fluxes between these compartments are dominated by the soil phase characteristic/composition, where partitioning of the $\mathrm{Hg}$ is concentrated. Mechanistically, the kinetics of $\mathrm{Hg}$ mobility can be broadly segregated into two groupings. The first is an immediate/ quick reaction scheme forming outer-sphere complexes involving cation exchange, with a multitude of different ligand types, both organic and inorganic. The other group involves the formation of stable colloid complexes that diffuse within the interior of the soil particles. The bonds formed are inner sphere and recalcitrant, characterized by slow release. However, these stores should not be considered as insignificant as they can provide a long-term and sustained source of bioavailable $\mathrm{Hg}$ [83, 84].
DGT has been shown to be effective at predicting $\mathrm{Hg}$ uptake in plants [85]. It acts to introduce a controlled perturbation into the soil system-replicating the processes evoked by the plant root. The method is also advantageous for in situ measurement of $\mathrm{Hg}$ speciation, because it preserves the stability and distribution of the $\mathrm{Hg}$ species, while also preconcentrating the target analyte during sampling [86]. DGT and HPLC-ICP-MS are appropriate tools for the evaluation of rhizosphere $\mathrm{Hg}$ bioavailability in estimating the risk from contaminated soils [84]. Liu et al. [85] predicted $\mathrm{MeHg}$ uptake by rice plants (Oryza sativa L.) by using the DGT technique to detect bioavailable $\mathrm{MeHg}$ in pore water; the DGT probe used a 3-mercaptophyl-FMSN. A significant positive correlation between $\mathrm{MeHg}$ flux in soil measured by DGT and MeHg flux in rice roots $(R=0.853$, $p<0.01)$ was observed. The correlation between these two flux parameters indicates that DGT can provide a quantitative description of the rate of update of this bioavailable $\mathrm{MeHg}$, and that the DGT can predict the bioavailability of $\mathrm{MeHg}$ in rice paddy soil [85]. Ridošková et al. [87] used Ambersep GT74 and Duolite GT73 gels as DGT binding layer for measuring the bioavailability of $\mathrm{Hg}$ in contaminated soils. The DGT experiments indicated that Duolite GT73 shows similar Hg accumulation properties as Ambersep GT74; the maximum $\mathrm{Hg}$ accumulation for these two resin gels was obtained after 12 days of deployment in the soil, about 27 and $33 \mathrm{ng} /$ disk, respectively. In four different soil deployment experiments, the range of DGT available $\mathrm{Hg}$ compared with total $\mathrm{Hg}$ ranged between 2 and 10\% [87]. Huu Nguyen et al. [88] measured the bioavailability of $\mathrm{Hg}$ in soil for the earthworm Eisenia Fetida by using DGT which used FMSN (3-mercaptopropyl-functionalized silica) as the binding phase. Soils used in $\mathrm{Hg}$ exposure experiments were prepared with different $\mathrm{pH}(4.6,5.6$, and 6.2) and varying peat moss concentrations of $5,10,15$, and $20 \%$. DGT was deployed in the soil with approximately 35-40 earthworms and removed across a series of timepoints spanning half-a-day through to 10 days. The calculated uptake efficiency for $\mathrm{Hg}$ for this binding gel was $91 \pm 3.4 \%$; the DGT was able to predict the $\mathrm{Hg}$ concentration of earthworm tissue effectively, unlike comparative measurements of pore water/acid-extractable Hg [88]. It can be seen that DGT is a dependable technique that can be used to measure the bioavailability of $\mathrm{Hg}$ in soil. Compared with other DGT, DGT using FMSN as the binding phase has better absorption efficiency for $\mathrm{Hg}$. For more research papers about $\mathrm{Hg}$ in situ sampling by DGT, see Table 2 .

\section{In Situ Sampling of As with DGT}

Arsenic is the 20th most abundant element in the earth's crust and can be present in the environment in four oxidation states $\mathrm{As}(-\mathrm{III}), \operatorname{As}(0), \mathrm{As}(\mathrm{III})$, and $\mathrm{As}(\mathrm{V})$ and as both organic and 
Table 2 A summary of FMSN and non-FMSN DGT configurations used for in situ sampling of $\mathrm{Hg}$

\begin{tabular}{|c|c|c|c|c|c|}
\hline Binding phase & Species & Matrix & $\begin{array}{l}\text { Dominant system/ } \\
\text { scheme }\end{array}$ & Key finding & Ref. \\
\hline $\begin{array}{l}\text { Chelex-100 and } \\
\text { Spheron-Thiol }\end{array}$ & $\begin{array}{l}\mathrm{MeHg}, \\
\quad \mathrm{CH} 3 \mathrm{CH} 2 \mathrm{Hg}+ \\
\mathrm{Hg}(\mathrm{II})\end{array}$ & Soil & $\begin{array}{l}\text { HPLC-ICP-MS, } \\
\text { DGT }\end{array}$ & $\begin{array}{l}\text { DGT techniques is a suitable tool for the } \\
\text { estimation of } \mathrm{Hg} \text { root availability and in } \\
\text { assessing the risk from contaminated } \\
\text { soils. }\end{array}$ & Cattani et al. [84] \\
\hline $\begin{array}{l}\text { Duolite GT73 and } \\
\text { Ambersep GT74 gel }\end{array}$ & $\operatorname{Hg}(\mathrm{II})$ & Water & DGT & $\begin{array}{l}\text { The agarose gel was found as a diffusion } \\
\text { gel for mercury measurement in DGT } \\
\text { techinique. }\end{array}$ & $\begin{array}{l}\text { Docekalová and } \\
\text { Diviš [89] }\end{array}$ \\
\hline $\begin{array}{l}\text { 3-mercaptopropyl-- } \\
\text { functionalized silica } \\
\text { (Sigma-Aldrich) }\end{array}$ & $\mathrm{Hg}(\mathrm{II}), \mathrm{MeHg}$ & Soil & DGT & $\begin{array}{l}\text { A new resin gel Ambersep GT74 was used } \\
\text { in DGT technology, which showed } \\
\text { similar Hg accumulation characteristics } \\
\text { to Duolite GT73. }\end{array}$ & Ridošková et al. [87] \\
\hline $\begin{array}{l}\text { 3-mercaptopropyl-- } \\
\text { functionalized silica } \\
\text { (Sigma-Aldrich) }\end{array}$ & $\mathrm{MeHg}$ & Soil & DGT & $\begin{array}{l}\text { Research shows that DGT can predict } \\
\text { bioavailability of } \mathrm{MeHg} \text { in paddy soil. }\end{array}$ & Liu et al. [85] \\
\hline $\begin{array}{l}\text { 3-mercaptopropyl-- } \\
\text { functionalized silica } \\
\text { (Sigma-Aldrich) }\end{array}$ & Total Hg & Soil & DGT & $\begin{array}{l}\text { DGT-measured } \mathrm{Hg} \text { flux is a better tool } \\
\text { than conventional methods for } \\
\text { predicting } \mathrm{Hg} \text { bioavailability for } \\
\text { earthworms inhabiting diverse types of } \\
\text { soil. }\end{array}$ & $\begin{array}{l}\text { Huu Nguyen et al. } \\
\text { [88] }\end{array}$ \\
\hline $\begin{array}{l}\text { 3-mercaptopropyl-- } \\
\text { functionalized silica } \\
\text { (Sigma-Aldrich) }\end{array}$ & Total Hg & Soil & DGT & $\begin{array}{l}\text { The effectiveness of DGT technology in } \\
\text { predicting plant uptake of mercury was } \\
\text { confirmed. }\end{array}$ & Turull et al. [90] \\
\hline $\begin{array}{l}\text { 3-mercaptopropyl-- } \\
\text { functionalized silica } \\
\text { (Sigma-Aldrich) }\end{array}$ & Total $\mathrm{Hg}, \mathrm{MeHg}$ & Water & DGT & $\begin{array}{l}\mathrm{Hg} \text { speciation in aquatic systems was } \\
\text { investaged, found that Labile } \mathrm{MeHg} \text { in } \\
\text { the sediment of the Gulf represents up to } \\
75 \% \text { of total labile } \mathrm{Hg} \text {. }\end{array}$ & Bratkič et al. [91] \\
\hline
\end{tabular}

inorganic species [92]. The general order of toxicity of the different arsenic species is as follows: arsenite $>$ arsenate $>$ monomethyl arsenate (MMA) $>$ dimethyl arsenate (DMA) $[92,93]$. While, the total content of As in the environment is largely decided by the degree of environmental pollution and associated geology. Localized redox conditions play a main role, along with the microbiome in controlling the concentrations of As(III) and As(V) [92], while methylation/ demethylation is subject to biotic controls $\mathrm{Su}$ et al. [94]. This creates a diverse range of As chemistries in situ that can be difficult to capture.

In 2012, Bennett et al. performed selective measurement of total inorganic arsenic and As(III) using separate DGT sampler units configured with different binders. Here, it was determined that As(III) was the main substance transferred from the sediment (solid phase) to pore water. They also showed that the DGT technology can be used under a range of deployment conditions to investigate arsenic morphology and its migration potential [95]. Wang et al. [96] used Zr-O DGT to systematically study the concentration variation of unstable As in the sediments of Hongze Lake; the recovery of $\mathrm{Zr}$ oxide DGT was $88 \%$. It was found that the concentration of labile As in the sediment profiles varied considerably (ranging from 0.15 to $\left.4.15 \mu \mathrm{g} \mathrm{L}{ }^{-1}\right)$ [96]. Gorny et al. [97] used a $\mathrm{Zn}$-ferrite $\left(\mathrm{ZnFe}_{2} \mathrm{O}_{4}\right)$ substrate as the DGT-binding phase to measure total arsenic in river water and sediment pore water. Results shown $\mathrm{ZnFe}_{2} \mathrm{O}_{4}$ have a better sorption capacity for As(III) compared with ferrihydrite and Metsorb binding gels, with the sorption capacity of $\mathrm{ZnFe}_{2} \mathrm{O}_{4}$ reaching 54,000 ng for As(III) [97]. In 2011, Bennett et al. first used FMSN as a DGT-binding substrate to selectively measure As(III), and its absorption efficiency for As(III) was > $99 \%$, validating the feasibility of this method. The reason why mercaptopropyl-silica have highly selective adsorption ability for $\mathrm{As}$ (III) is because of the strong complexation of $\mathrm{H}_{3} \mathrm{AsO}_{3}$ by thiol (S-H) groups [98]. Gorny et al. [99] also reported on the use of FMSN as the DGT-binding layer and found that the use of matrix corrected elution factors to rectify the interaction with sulfides can ameliorate the measurement of As(III) in 3mercapto-silica (3MP)-binding gels; the concentration of As(III) recovered from the 3MP-DGT samplers reached 103 \pm 7.0 and $93.8 \pm 8.6 \%$ (mean \pm standard deviation) of the initial As(III) concentration in seawater and freshwater, respectively [99] (Table 3).

\section{DGT-Two-Dimensional Chemical Imaging}

The acquisition of environmental/soil measurements in the majority of studies to date prioritizes the sampling of 
Table 3 A summary of FMSN and non-FMSN DGT configurations used for in situ sampling of As

\begin{tabular}{|c|c|c|c|c|c|}
\hline Binding phase & Species & Matrix & $\begin{array}{l}\text { Dominant system/ } \\
\text { scheme }\end{array}$ & Key finding & Ref. \\
\hline $\begin{array}{l}\text { Metsorb and } \\
\text { mercapto-silica }\end{array}$ & $\begin{array}{l}\text { Total inorganic } \\
\text { arsenic and } \\
\text { As(III) }\end{array}$ & $\begin{array}{l}\text { Water and } \\
\text { sediment }\end{array}$ & DGT, DET, ICP-MS & $\begin{array}{l}\text { Demonstrated the capabilities of the } \\
\text { DGT and DET techniques for } \\
\text { investigating arsenic speciation and } \\
\text { mobilization over a range of } \\
\text { sediment conditions. }\end{array}$ & Bennett et al. [95] \\
\hline $\begin{array}{l}\text { Zirconium }(\mathrm{Zr}) \\
\text { oxide and } \\
\text { 3-mercaptopropyl-- } \\
\text { functionalized silica }\end{array}$ & Total As & Sediment & $\begin{array}{l}\text { DGT, atomic } \\
\text { fluorescence } \\
\text { spectrometry (AFS) }\end{array}$ & $\begin{array}{l}\text { Prove DGT is a reliable and } \\
\text { high-resolution technique that can be } \\
\text { used for in situ monitoring of the } \\
\text { labile fractions of As and } \mathrm{Hg} \text { in } \\
\text { sediment in fresh water bodies. }\end{array}$ & Wang et al. [96] \\
\hline $\begin{array}{l}\text { Ferrihydrite }(\mathrm{Fe}) \text { and } \\
\text { titanium dioxide }(\mathrm{Ti})\end{array}$ & As(III) & Water & DGT, DET, ICP-MS & $\begin{array}{l}\text { The concentration of arsenic in the pore } \\
\text { water of contaminated rice fields was } \\
\text { measured, and the importance of } \\
\text { pore water in the measurement of } \\
\text { arsenic was emphasized. }\end{array}$ & Garnier et al. [100] \\
\hline $\begin{array}{l}\mathrm{Zn} \text {-ferrite ( } \mathrm{ZnFe} 2 \mathrm{O} 4) \\
\text { and } \\
\text { 3-mercaptopropyl-- } \\
\text { functionalized silica }\end{array}$ & $\begin{array}{l}\text { Total As and } \\
\text { As(III) }\end{array}$ & Sediment & DGT, ICP-MS & $\begin{array}{l}\text { The new } \mathrm{Zn} \text {-ferrite binding gel is well } \\
\text { adapted for determining total As } \\
\text { concentrations, and phosphate } \\
\text { interference on As measurements has } \\
\text { been demonstrated whatever the } \\
\text { binding gel. }\end{array}$ & Gorny et al. [97] \\
\hline $\begin{array}{l}\text { 3-mercaptopropyl-- } \\
\text { functionalized silica } \\
\text { and Metsorb }\end{array}$ & $\begin{array}{l}\text { Total inorganic } \\
\text { arsenic and } \\
\text { As(III) }\end{array}$ & Water & DGT, ICP-MS & $\begin{array}{l}\text { First used } \\
\text { 3-mercaptopropyl-functionalized } \\
\text { silica as DGT binding phase to } \\
\text { selectively measure As (III), and } \\
\text { proved the feasibility of this method. }\end{array}$ & Bennett et al. [98] \\
\hline $\begin{array}{l}\text { 3-mercaptopropyl-- } \\
\text { functionalized silica, } \\
\text { ferrihydrite, Metsorb, } \\
\text { zinc ferrite, and } \\
\text { zirconium dioxide }\end{array}$ & $\begin{array}{l}\text { Total As and } \\
\text { As(III) }\end{array}$ & Sediment & DGT, ICP-MS & $\begin{array}{l}\text { Comparison of the adsorption capacity } \\
\text { of different binding gels and found } \\
\text { that the use of unconventional elution } \\
\text { factors to correct the interaction with } \\
\text { sulfides can improve the } \\
\text { determination of As (III) in } \\
\text { 3-mercaptopropyl-functionalized } \\
\text { silica binding gels. }\end{array}$ & Gorny et al. [99] \\
\hline
\end{tabular}

individual biogeochemical compartments. Far less consideration is given to the speciation, transformation, and exchange of elements across interfaces between different niches/zones, and the processes controlling these events. 2D high-resolution diffusive gradients in thin films (HR-DGT) are a key component of one of the few existing tools that can capture multielemental solute dynamics/interactions in appropriate submillimeter scales, to suitably understand/decipher interface fluxes. The usual operation of this chemical imaging approach uses a multi-layered system of DGT and planar optodes to obtain the HR-2D images. This is not intended to be a comprehensive review of this emerging technology; for this, we recommend Santner et al. [101] and Santner and Williams [102]. However, FMSN are increasingly been used in these ion-mapping applications, because of their high capacities, environmental tolerances, and species specificity. For example, Shi et al. [103], through mapping the 2D chemistry of a rice rhizosphere, were able to capture the distribution of Se(IV) and oxygen simultaneously. Here, the DGT substrate used was a bi-functionalized SBA15 FMSN, which provided a selective measurement for Se(IV) (Fig. 3) [103]. What was apparent from these chemical images was that Se(IV) mobility is restricted to the rooting zone and with localized redox conditions controlling release patterns. This is despite the Se amendments having been thoroughly mixed through the soils prior to the addition of the rice plants.

This recent interest in the root-soil interactions within rice rhizospheres is understandable. Rice is so widely cropped and plays a fundamental role in global food security, yet is significantly threatened by trace element imbalances, either deficiencies or over-exposure. The belowground processes around the roots are very challenging to measure because of the complexity and instability of the environment due to strong zonation in both chemical and biological effects. This means that there is still much to learn about the biogeochemistry of paddy soils and in particular the role of these fine-scale, localized features on plant health and quality. This is demonstrated by the recent 

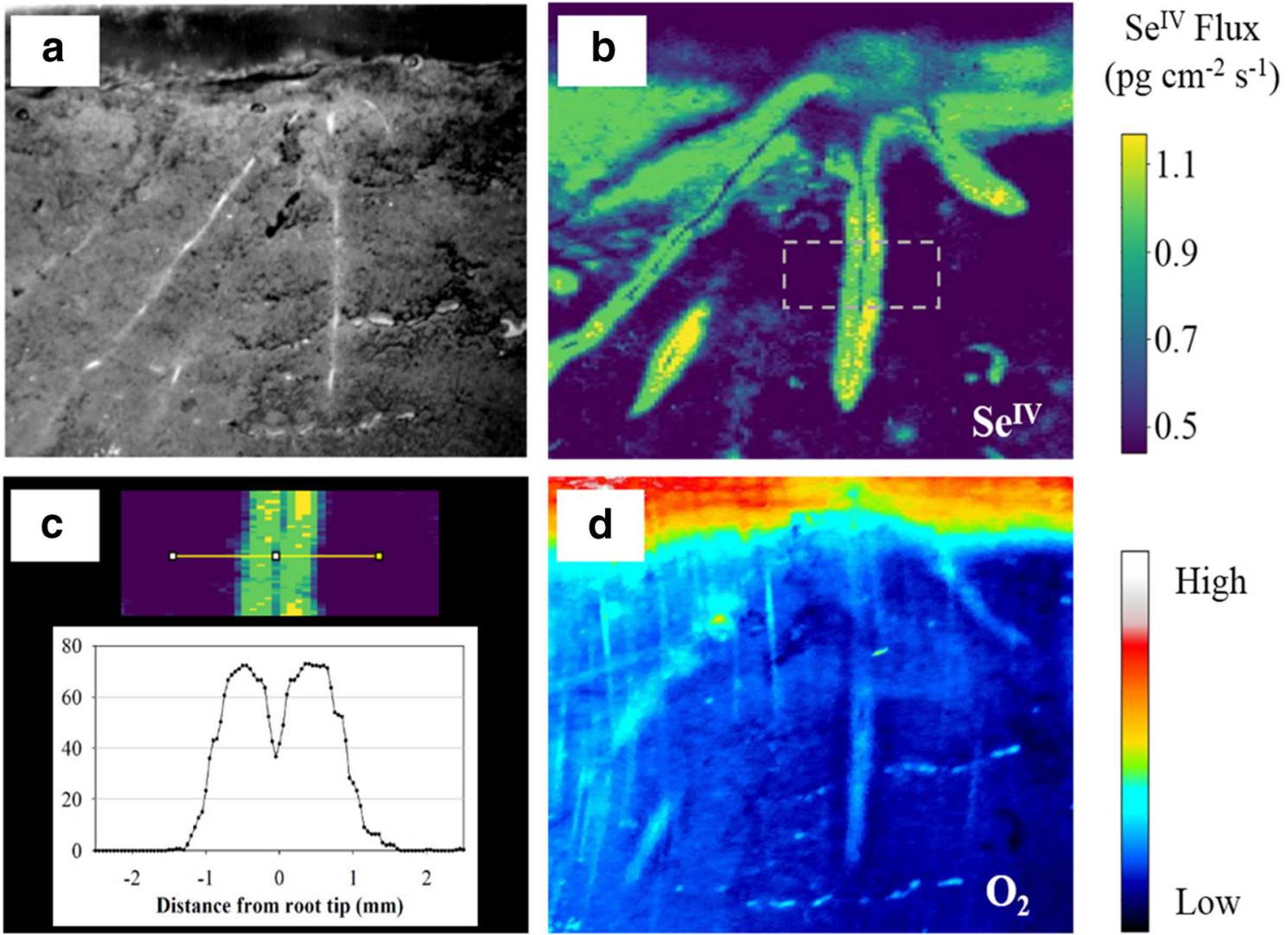

Fig. 3 Two-dimensional representation of $\mathrm{Se}^{\mathrm{IV}}$ and $\mathrm{O}_{2}$ around a set of rice root. a Photograph of rice root grown in Se-contaminated soil. b Visualization of $\mathrm{Se}^{\mathrm{IV}}$ around a set of rice roots. The outlined position of root that is featured in (c) is indicated by gray dash markings. $\mathbf{c} \mathrm{Se}^{\mathrm{IV}}$ species in the soil solution with distance from the root zone. d Oxygen distribution imaged by an $\mathrm{O} 2$ planar optode sensor [103]. Reprinted with permission from Shi X, Fang W, Tang N, Williams P, Hu X, Liu Z, Yin $\mathrm{D}, \mathrm{Ma} \mathrm{L}$, and Luo J. In situ selective measurement of Se(IV) in waters and soils: diffusive gradients in thin-films with bi-functionalized silica nanoparticles. Environmental Science \& Technology. 2018;52(24):14140-14148.). Copyright (2020) American Chemical Society

hotspots of mobilization that formed around root tip zones, similar to the patterns observed for As and $\mathrm{Pb}[104,105]$.

Traditionally, to extend the range of element/species measurements captured by the DGT/optode systems, binders have been mixed together, or the combination of binder layers has been increased. What is exciting about FMSN approaches is that these properties can be potentially delivered by one binder phase, given the correct functionalization approach, providing a molecularbased solution to expanding and improving chemical imaging delivery.

\section{Limitations and Considerations for FMSN Use in Soils}

As documented in this review, FMSN are a diverse and rapidly developing class of materials with a wide array of different physio-chemical properties. However, there is still a lot that remains unknown about the immediate and persistent effects these incredibly versatile and varied materials can have 
(a) $\mathrm{O}_{2}$

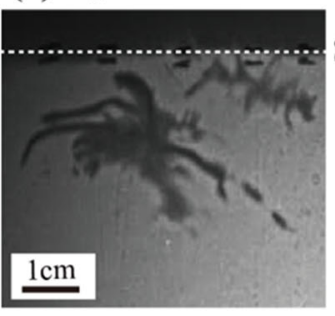

(d) $\mathrm{Fe}$

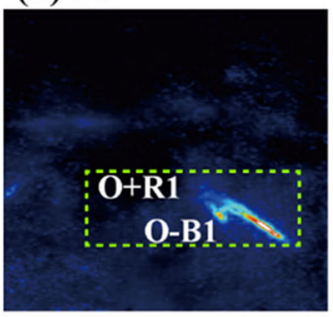

(e) $\mathrm{Mn}$

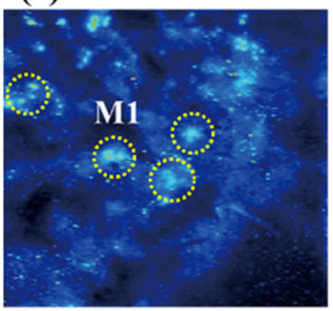

(b) $3 \mathrm{D} \mathrm{O}_{2}$
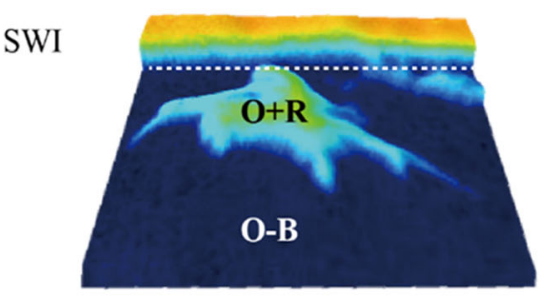

(f) PCA plots

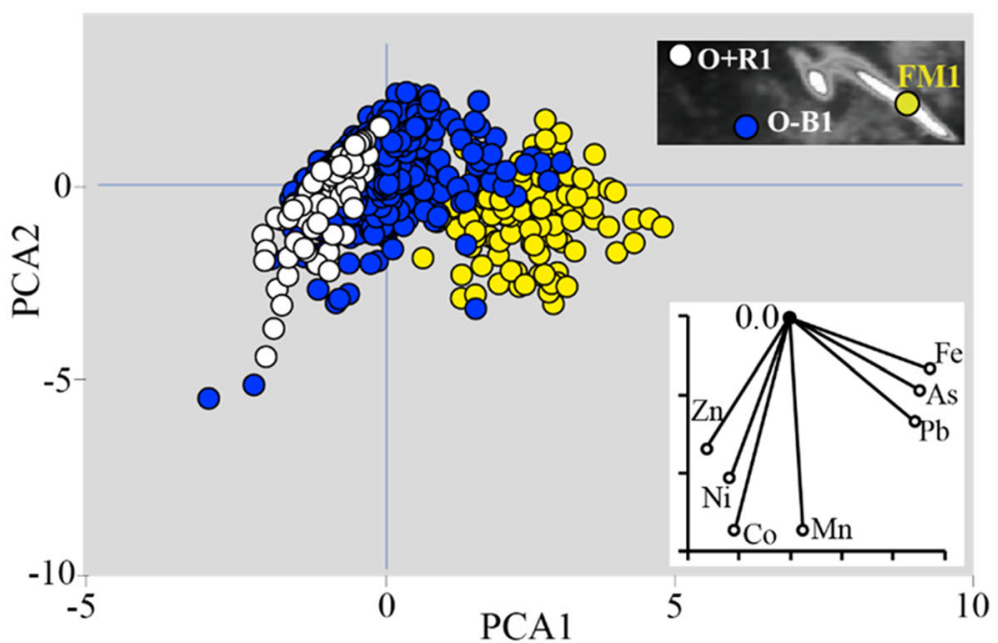

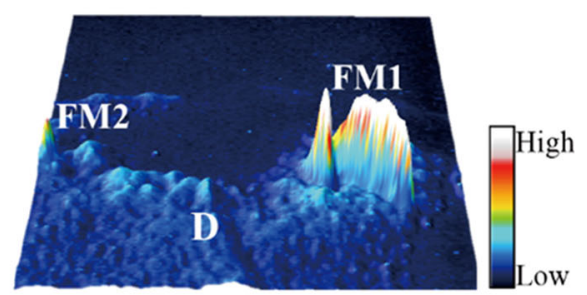

(c) $3 \mathrm{D} \mathrm{As}$
Fig. 4 Solute fluxes around a set of four-week-old rice roots with SPRIDA DGT and $\mathrm{O}_{2}$ planar optodes. a Image of $\mathrm{O}_{2}$ distribution obtained before the deployment of the sandwich sensor. The horizontal-dashed lines show the soil-water interface (SWI). b 3D plot of $\mathrm{O}_{2}$ distribution in the rice rhizosphere with the sandwich sensor, $\mathrm{O}+\mathrm{R}$ indicates the aerobic rhizosphere, O-B indicates the anaerobic bulk area. $\mathbf{c} 3 \mathrm{D}$ plot of As fluxes in rice rhizosphere with the sandwich sensor. FM indicates flux maxima around the root tip apice. D indicates the flux depletion zones. d Fe fluxes in the rhizosphere. The green box shows the corresponding data extraction region/transect used for PCA analysis. e Mn fluxes in the rhizosphere. The yellow circles indicate flux microniches (label as M1). f PCA plot of elements in different regions, aerobic rhizosphere $(\mathrm{O}+\mathrm{R})$,

non-rhizosphere/anaerobic soil (O-B), and flux maximal around root tip apice (FM1). For all images, the metal fluxes $\left(f_{\mathrm{DGT}}, \mathrm{pg} \mathrm{cm}^{-2} \mathrm{~s}^{-1}\right)$ and oxygen concentration (percent air saturation) increased sequentially with the color scale shown from blue to white. The scales in the figure represent the following ranges from 0 to $100 \%$ for $\mathrm{O}_{2}$, from 0.004 to 0.126 for As, from 0 to 42.144 for $\mathrm{Fe}$, and from 0.71 to 22.39 for $\mathrm{Mn}$ [104]. Reprinted with permission from Yin D, Fang W, Guan D, Williams P, Moreno-Jimenez E, Gao Y, Zhao F, Ma L, Zhang H, and Luo J. Localized intensification of arsenic release within the emergent rice rhizosphere. Environmental Science \& Technology. 2020;54(6):3138-3147.). Copyright (2020) American Chemical Society

example, in addition to the widely known antagonisms associated with $\mathrm{Si}$ and $\mathrm{As}(\mathrm{III})$ uptake in plants. It has recently been observed that $\mathrm{SiO}_{2}$ nanoparticles (NPs) provide additional protection to plant cells subject to As stress, mediating a strengthening of plant cell walls by increasing their thickness and altering their composition [106]. Likewise, in maize, field applications of $\mathrm{SiO}_{2}$-NPs resulted in a large improvement to growth, but interestingly, there were disruptive effects as well with the Si found to induce a pesticide response for the crop during storage [107]. Similarly, some soil invertebrates demonstrate avoidance behaviors to $\mathrm{SiO}_{2} \mathrm{NP}$ Santos et al. [108], and it has been shown that they can increase soil bacteria community diversity [109].

$\mathrm{SiO}_{2} \mathrm{NP}$ place within the top five commercial nanoproducts globally $[108,110]$ with applications ranging from paint 
Fig. 5 Photograph of rice root after planting in the blank soil (C) and the soil treated with $100 \mathrm{mg}$ $\mathrm{kg}^{-1}$ sulfur (S) (top). Highresolution $2 \mathrm{D}$ profiles of $\mathrm{Sb}^{\mathrm{III}}$ and dissolved sulfide in the rhizosphere of rice obtained by MSBA-DGT (middle) and AgIDGT (bottom) for 24-h deployments, respectively [74]. Reprinted with permission from Fang W, Shi X, Yang D, Hu X, Williams P, Shi B, Liu Z, and Luo $\mathrm{J}$. In situ selective measurement based on diffusive gradients in thin films technique with mercapto-functionalized mesoporous silica for highresolution imaging of $\mathrm{Sb}$ (III) in soil. Analytical Chemistry. 2020;92(5):3581-3588.). Copyright (2020) American Chemical Society
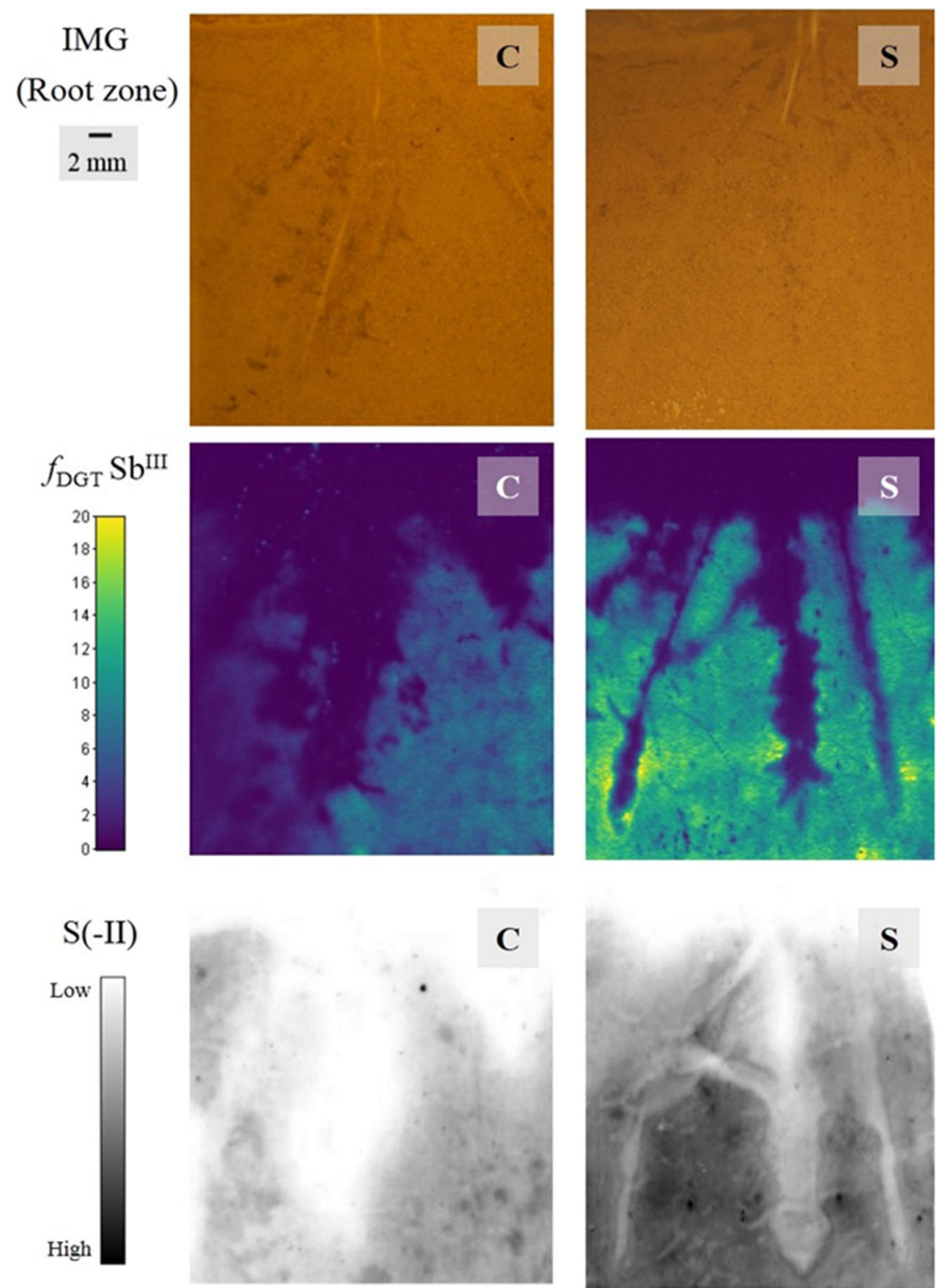

stabilizers through to food agents [111]. Therefore, extensive material flows of $\mathrm{SiO}_{2} \mathrm{NP}$ into the environment are already ongoing [111]. However, when trying to isolate and understand the already complex mechanisms of FMSN interactions within the plant-soil continuum, it would be prudent to work initially with larger particle size FMSN. Not only would these have more predictable mobility in soils but they would simplify the interpretation of the soil chemical trends, making it easier to match a specific functionalization to its response in situ.

\section{Outlook/Conclusion}

Global soil health continues to be threatened by trace element pollution. This damage is inextricably linked to our continued intensive agri and industrial activities, demand for natural resources, and poor waste management and material recycling/ reuse. This land degradation can be broadly viewed as either a general increase in metal loading into soil systems, or modification of existing elemental reservoirs, or a mixture of both processes which results in enhanced bioavailability and toxicity. New technologies are required to counter these pollution challenges, and the behavior and properties of FMSN are highly suitable for this mission. Firstly, Si is already a major constituent of soils, and is highly stable in the environment. It is these traits that provide a cost-effective and resistant platform from which to optimize the functionalization which in combination with the architecture of the pores and channel networks within the $\mathrm{Si}$ controls the binding chemistries and their specificities to desired targets. These dual physical and chemical "levers" enable the production of materials with a 
wide range of behaviors and characteristics that can be controlled very precisely by the developers. Used predominantly to clean waters and "wet" waste discharges, there is exciting potential for more soil applications to reduce toxic metal uptake in crops and as permeable reactive barriers to halt pollutant plume migrations and protect vulnerable groundwaters.

The other aspect of FMSN applications is in their role in environmental measurement. In this review, we have focused on the use of FMSN in the widely used/popular passive sampler DGT, examining this from the perspective of two soil pollutant priorities $\mathrm{Hg}$ and $\mathrm{As}$, alongside the emerging new DGT applications of HR-2D ion-mapping. In conclusion, the benefits FMSN in an environmental setting are gaining increasing attention, as more application successes continue to be shown. The versatility of the FMSN platforms is perhaps best illustrated by their large range of uses, fulfilling a research need across the diverse themes of pollutant characterization, analysis, monitoring, prevention, treatment, and remediation. However, there is still much to be discovered about how FMSN perform in different soil environments, especially in wetland agri-ecosystems like rice paddies where inorganic pollutants such as As are of particular concern [105, 112]. It is in these systems where in order to improve air quality, worldwide bans on rice straw burning have resulted in the repurposing of the straw which was once cycled back into the soil. This export removes millions of tonnes of $\mathrm{Si}$. This is of concern because of links Si depletion has on harvest failures, rampant pest/disease outbreaks, and enhanced plant uptake of As [113]. How FMSN could play a role in efforts to resupply Si to these damaged soils is still unresolved, but certainly for the worst metal-impacted sites, its use carries appeal.

\begin{abstract}
Acknowledgments We would like to acknowledge the Department of Science and Technology of Guizhou Province (贵州省科技厅), Guizhou Service Center For Academician Expert (贵州省院士专家服务中心), Guizhou Forestry Bureau (贵州省林业局), Department of Agriculture and Rural Areas of Guizhou Province (贵州省农业农村厅), State Key Laboratory of Efficient Utilization for Low Grade Phosphate Rock and its Associated Resources (Registration No.: 2015DQ820763) for technical advice related to functionalised materials and their applications, soil amendments, fertilizer management, and TTE pollution management.
\end{abstract}

Funding Information The financial support of Science Foundation Ireland and the Northern Ireland Department of Education and Learning, through grant 14/IA/2371, is gratefully acknowledged. The authors thank GoldenKeys High-tech Materials Co., Ltd. (Registration No.: 91520900MA6DL1ER7N), for project funding and collaboration and the GoldenKeys' Science and Technology Association for international meetings and conference support. Finally, grant FAPESP-2018/ 17069-7 is recognized for financial support.

\section{Compliance with Ethical Standards}

Conflict of Interest The authors declare that they have no conflict of interest
Human and Animal Rights and Informed Consent This article does not contain any studies with human or animal subjects performed by any of the authors.

Open Access This article is licensed under a Creative Commons Attribution 4.0 International License, which permits use, sharing, adaptation, distribution and reproduction in any medium or format, as long as you give appropriate credit to the original author(s) and the source, provide a link to the Creative Commons licence, and indicate if changes were made. The images or other third party material in this article are included in the article's Creative Commons licence, unless indicated otherwise in a credit line to the material. If material is not included in the article's Creative Commons licence and your intended use is not permitted by statutory regulation or exceeds the permitted use, you will need to obtain permission directly from the copyright holder. To view a copy of this licence, visit http://creativecommons.org/licenses/by/4.0/.

\section{References}

1. Weiser D, Boros Z, Nagy J, Hornyánszky G, Bell E, Sátorhelyi P, et al. Chapter 15 SynBiocat: protein purification, immobilization and continuous-flow processes. An Industrial Perspective. The Royal Society of Chemistry: Biocatalysis; 2017.

2. Jurado-Gonzalez M, Li Ou D, Sullivan A, Wilson J. Synthesis, characterisation and catalytic activity of porous vanadyl phosphonate-modified silicas. J Mater Chem. 2002;12(12): 3605-9.

3. Al-Hashimi M, Roy G, Sullivan A, Wilson J. Selective oxidations of sulfides to sulfoxides using immobilised cerium alkyl phosphonate. Tetrahedron Lett. 2005;46(25):4365-8.

4. Slowing I, Vivero-Escoto J, Trewyn B, Lin V. Mesoporous silica nanoparticles: structural design and applications. J Mater Chem. 2010;20(37):7924.

5. Yang H, Ozin G, Kresge C. The role of defects in the formation of mesoporous silica fibers, films, and curved shapes. Adv Mater. 1998;10(11):883-7.

6. Zhao D. Triblock copolymer syntheses of mesoporous silica with periodic 50 to 300 angstrom pores. Science. 1998;279(5350):54852.

7. Buzea C, Pacheco I, Robbie K. Nanomaterials and nanoparticles: sources and toxicity. Biointerphases. 2007;2(4):MR17-71.

8. Kresge C, Leonowicz M, Roth W, Vartuli J, Beck J. Ordered mesoporous molecular sieves synthesized by a liquid-crystal template mechanism. Nature. 1992;359(6397):710-2.

9. Bibby A, Mercier L. Mercury (II) ion adsorption behavior in thiolfunctionalized mesoporous silica microspheres. Chem Mater. 2002;14(4):1591-7.

10. Jadhav S. Incredible pace of research on mesoporous silica nanoparticles. Inorg Chem Front. 2014;1(10):735-9.

11. Asadullah M, Jahan I, Ahmed M, Adawiyah P, Malek N, Rahman M. Preparation of microporous activated carbon and its modification for arsenic removal from water. J Ind Eng Chem. 2014;20(3): 887-96.

12. Niazi L, Lashanizadegan A, Sharififard H. Chestnut oak shells activated carbon: preparation, characterization and application for $\mathrm{Cr}$ (VI) removal from dilute aqueous solutions. J Clean Prod. 2018;185:554-61.

13. Grover D, Zhou J, Frickers P, Readman J. Improved removal of estrogenic and pharmaceutical compounds in sewage effluent by full scale granular activated carbon: impact on receiving river water. J Hazard Mater. 2011;185(2-3):1005-11.

14. Sawant S, Munusamy K, Somani R, John M, Newalkar B, Bajaj H. Precursor suitability and pilot scale production of super 
activated carbon for greenhouse gas adsorption and fuel gas storage. Chem Eng J. 2017;315:415-25.

15. Arena N, Lee J, Clift R. Life cycle assessment of activated carbon production from coconut shells. J Clean Prod. 2016;125:68-77.

16. Kim M, Kim K, Park S, Roh K. Hierarchically structured activated carbon for ultracapacitors. Scientific Reports. 2016a;6(1).

17. Kim K, Kabir E, Jahan S. A review on the distribution of Hg in the environment and its human health impacts. J Hazard Mater. 2016b;306:376-85.

18. Rashidi N, Yusup S. Potential of palm kernel shell as activated carbon precursors through single stage activation technique for carbon dioxide adsorption. J Clean Prod. 2017;168:474-86.

19. Mohamad Nor N, Lau L, Lee K, Mohamed A. Synthesis of activated carbon from lignocellulosic biomass and its applications in air pollution control — a review. J Environ Chem Eng. 2013;1(4): 658-66.

20. Yagmur E, Ozmak M, Aktas Z. A novel method for production of activated carbon from waste tea by chemical activation with microwave energy. Fuel. 2008;87(15-16):3278-85.

21. Ahmed M, Hasan Johir M, Zhou J, Ngo H, Nghiem L, Richardson $\mathrm{C}$, et al. Activated carbon preparation from biomass feedstock: clean production and carbon dioxide adsorption. J Clean Prod. 2019;225:405-13.

22. Bansal R, Goyal M. Activated carbon adsorption. Boca Raton: Taylor \& Francis / CRC Press; 2005.

23. El Gamal M, Mousa H, El-Naas M, Zacharia R, Judd S. Bioregeneration of activated carbon: a comprehensive review. Sep Purif Technol. 2018;197:345-59.

24. Vega E, Lemus J, Anfruns A, Gonzalez-Olmos R, Palomar J, Martin M. Adsorption of volatile sulphur compounds onto modified activated carbons: effect of oxygen functional groups. Journal of Hazardous Materials. 2013;258-259:77-83.

25. Molina-Sabio M, Gonçalves M, Rodríguez-Reinoso F. Oxidation of activated carbon with aqueous solution of sodium dichloroisocyanurate: effect on ammonia adsorption. Microporous Mesoporous Mater. 2011;142(2-3):577-84.

26. Zbigniew H, Dorota K. Chapter 8: Selective removal of heavy metal ions from waters and waste waters using ion exchange methods. In: Ayben K, editor. Ion exchange technologies. Turkey: Istanbul University; 2012. https://doi.org/10.5772/51040.

27. Levchuk I, Rueda Márquez J, Sillanpää M. Removal of natural organic matter (NOM) from water by ion exchange - a review. Chemosphere. 2018;192:90-104.

28. Inglezakis V, Poulopoulos S. Adsorption, ion exchange and catalysis. Amsterdam: Elsevier; 2006.

29. Arges C, Ramani V. Two-dimensional NMR spectroscopy reveals cation-triggered backbone degradation in polysulfone-based anion exchange membranes. Proc Natl Acad Sci. 2013;110(7):2490-5.

30. Yuan Z, Li X, Hu J, Xu W, Cao J, Zhang H. Degradation mechanism of sulfonated poly(ether ether ketone) (SPEEK) ion exchange membranes under vanadium flow battery medium. Phys Chem Chem Phys. 2014;16(37):19841-7.

31. Arm S, Blanchard D, Fiskum S. Chemical degradation of an ion exchange resin processing salt solutions. Sep Purif Technol. 2005;43(1):59-69.

32. Sharaf G, Hassan H. Removal of copper ions from aqueous solution using silica derived from rice straw: comparison with activated charcoal. Int J Environ Sci Technol. 2013;11(6):1581-90.

33. Li P, Wang J, Li X, Zhu W, He S, Han C, et al. Facile synthesis of amino-functional large-size mesoporous silica sphere and its application for $\mathrm{Pb}^{2+}$ removal. J Hazard Mater. 2019;378:120664.

34. Monnier A, Schuth F, Huo Q, Kumar D, Margolese D, Maxwell $\mathrm{R}$, et al. Cooperative formation of inorganic-organic interfaces in the synthesis of silicate mesostructures. Science. 1993;261(5126): 1299-303.
35. Huo Q, Margolese D, Ciesla U, Feng P, Gier T, Sieger P, et al. Generalized synthesis of periodic surfactant/inorganic composite materials. Nature. 1994;368(6469):317-21.

36. Bagshaw S, Prouzet E, Pinnavaia T. Templating of mesoporous molecular sieves by nonionic polyethylene oxide surfactants. Science. 1995;269(5228):1242-4.

37. Yang H, Coombs N, Ozin G. Morphogenesis of shapes and surface patterns in mesoporous silica. Nature. 1997;386(6626):6925 .

38. Richer R, Mercier L. Direct synthesis of functional mesoporous silica by neutral $\mathrm{pH}$ nonionic surfactant assembly: factors affecting framework structure and composition. Chem Mater. 2001;13(9): 2999-3008.

39. Boissière C, Larbot A, van der Lee A, Kooyman P, Prouzet E. A new synthesis of mesoporous MSU-X silica controlled by a twostep pathway. Chem Mater. 2000;12(10):2902-13.

40. Tanev P, Pinnavaia T. Mesoporous silica molecular sieves prepared by ionic and neutral surfactant templating: a comparison of physical properties. Chem Mater. 1996;8(8):2068-79.

41. Prouzet E, Cot F, Nabias G, Larbot A, Kooyman P, Pinnavaia T. Assembly of mesoporous silica molecular sieves based on nonionic ethoxylated sorbitan esters as structure directors. Chem Mater. 1999;11(6):1498-503.

42. Mercier L, Pinnavaia T. Direct synthesis of hybrid organic-inorganic nanoporous silica by a neutral amine assembly route: structure-function control by stoichiometric incorporation of organosiloxane molecules. Chem Mater. 2000;12(1):188-96.

43. Yu C, Fan J, Tian B, Zhao D. Morphology development of mesoporous materials: a colloidal phase separation mechanism. Chem Mater. 2004;16(5):889-98.

44. Zhao D, Sun J, Li Q, Stucky G. Morphological control of highly ordered mesoporous silica SBA-15. Chem Mater. 2000;12(2): 275-9.

45. Peng J, Liu J, Liu J, Yang Y, Li C, Yang Q. Fabrication of coreshell structured mesoporous silica nanospheres with dually oriented mesochannels through pore engineering. J Mater Chem A. 2014;2(21):8118-25.

46. Qin Q. Technology and principle for pollution adsorption by mesoporous silica-based materials. Nanjing: Southeast University; 2015.

47. Mamonov N, Mikhailov S, Dzhungurova G, Bessudnov A, Grigor'ev D, Bedrina I, et al. Investigation of $\mathrm{CO}_{2}$ adsorption on amine-functionalized silicas and metal-organic polymers. Russ Chem Bull. 2018;67(9):1595-600.

48. Mercier L, Pinnavaia T. Access in mesoporous materials: advantages of a uniform pore structure in the design of a heavy metal ion adsorbent for environmental remediation. Adv Mater. 1997;9(6): $500-3$.

49. Zhang W, Pauly T, Pinnavaia T. Tailoring the framework and textural mesopores of HMS molecular sieves through an electrically neutral $\left(\mathrm{S}^{\circ} \mathrm{I}^{\circ}\right)$ assembly pathway. Chem Mater. 1997;9(11): 2491-8.

50. Moller K, Bein T. Inclusion chemistry in periodic mesoporous hosts. Chem Mater. 1998;10(10):2950-63.

51. Mercier L, Pinnavaia T. Heavy metal ion adsorbents formed by the grafting of a thiol functionality to mesoporous silica molecular sieves: factors affecting $\mathrm{Hg}(\mathrm{II})$ uptake. Environ Sci Technol. 1998;32(18):2749-54.

52. Blitz I, Blitz J, Gun'ko V, Sheeran D. Functionalized silicas: structural characteristics and adsorption of $\mathrm{Cu}$ (II) and $\mathrm{Pb}$ (II). Colloids Surf A Physicochem Eng Asp. 2007;307(1-3):83-92.

53. Fan H, Li J, Li Z, Sun T. An ion-imprinted amino-functionalized silica gel sorbent prepared by hydrothermal assisted surface imprinting technique for selective removal of cadmium (II) from aqueous solution. Appl Surf Sci. 2012;258(8):3815-22. 
54. Chandra D, Das S, Bhaumik A. A fluorophore grafted 2Dhexagonal mesoporous organosilica: excellent ion-exchanger for the removal of heavy metal ions from wastewater. Microporous Mesoporous Mater. 2010;128(1-3):34-40.

55. Nabil M, Mahmoud K, El-Shaer A, Nayber H. Preparation of crystalline silica (quartz, cristobalite, and tridymite) and amorphous silica powder (one step). J Phys Chem Solids. 2018;121: 22-6.

56. Zhang Q, Lee I, Ge J, Zaera F, Yin Y. ChemInform abstract: surface-protected etching of mesoporous oxide shells for the stabilization of metal nanocatalysts. ChemInform. 2010;41(40): 2201-14.

57. Hoffmann F, Cornelius M, Morell J, Froeba M. Silica-based mesoporous organic - inorganic hybrid materials. ChemInform. 2006;37(34)

58. Lian M, Feng Q, Wang L, Niu L, Zhao Z, Li X, et al. Highly effective immobilization of $\mathrm{Pb}$ and $\mathrm{Cd}$ in severely contaminated soils by environment-compatible, mercapto-functionalized reactive nanosilica. J Clean Prod. 2019;235:583-9.

59. Li S, Jiao X, Yang H. Hydrophobic core/hydrophilic shell structured mesoporous silica nanospheres: enhanced adsorption of organic compounds from water. Langmuir. 2013;29(4):1228-37.

60. Yang H, Zhang G, Hong X, Zhu Y. Silylation of mesoporous silica MCM-41 with the mixture of $\mathrm{Cl}\left(\mathrm{CH}_{2}\right)_{3} \mathrm{SiCl}_{3}$ and $\mathrm{CH}_{3} \mathrm{SiCl}_{3}$ : combination of adjustable grafting density and improved hydrothermal stability. Microporous Mesoporous Mater. 2004;68(1-3):119-25.

61. Zhu G, Yang Q, Jiang D, Yang J, Zhang L, Li Y, et al. Synthesis of bifunctionalized mesoporous organosilica spheres for highperformance liquid chromatography. J Chromatogr A. 2006;1103(2):257-64.

62. Georgescu I, Mureșeanu M, Cârjă G, Hulea V. Adsorptive removal of cadmium and copper from water by mesoporous silica functionalized with N-(Aminothioxomethyl)-2-Thiophen carboxamide. J Environ Eng. 2013;139(10):1285-96.

63. Xia K, Ferguson R, Losier M, Tchoukanova N, Brüning R, Djaoued Y. Synthesis of hybrid silica materials with tunable pore structures and morphology and their application for heavy metal removal from drinking water. J Hazard Mater. 2010;183(1-3): $554-64$.

64. Lewandowski D, Bajerlein D, Schroeder G. Adsorption of hydrogen peroxide on functionalized mesoporous silica surfaces. Struct Chem. 2014;25(5):1505-12.

65. Zhou Y, He Z, Tao Y, Xiao Y, Zhou T, Jing T, et al. Preparation of a functional silica membrane coated on $\mathrm{Fe}_{3} \mathrm{O}_{4}$ nanoparticle for rapid and selective removal of perfluorinated compounds from surface water sample. Chem Eng J. 2016;303:156-66.

66. Chatterjee S, Paital A. Functionalized cubic mesoporous silica as a non-chemodosimetric fluorescence probe and adsorbent for selective detection and removal of bisulfite anions along with toxic metal ions. Adv Funct Mater. 2017;28(9):1704726.

67. Lee J, Chen $\mathrm{C}$, Cheng $\mathrm{S}$, Li H. Adsorption of $\mathrm{Pb}$ (II) and $\mathrm{Cu}$ (II) metal ions on functionalized large-pore mesoporous silica. Int J Environ Sci Technol. 2015;13(1):65-76.

68. Wang Y, Zhu L, Guo B, Chen S, Wu W. Mesoporous silica SBA15 functionalized with phosphonate derivatives for uranium uptake. New J Chem. 2014;38(8):3853-61.

69. The Goldenkeys. 2020. http://www.thegoldenkeys.com.cn/. Accessed 26 May 2020.

70. Shen S, Pan T, Liu X, Yuan L, Wang J, Zhang Y, et al. Adsorption of Rh(III) complexes from chloride solutions obtained by leaching chlorinated spent automotive catalysts on ion-exchange resin Diaion WA21J. J Hazard Mater. 2010;179(1-3):104-12.

71. Yao S, Zhang J, Shen D, Xiao R, Gu S, Zhao M, et al. Removal of $\mathrm{Pb}$ (II) from water by the activated carbon modified by nitric acid under microwave heating. J Colloid Interface Sci. 2016;463:118 27.

72. Casado N, Morante-Zarcero S, Pérez-Quintanilla D, Sierra I. Evaluation of mesostructured silicas with wormhole-like framework functionalized with hydrophobic groups as alternative sorbents for extraction of drug residues from food samples. Mater Lett. 2018;220:165-8.

73. Wang Y, Liu Y, Zhan W, Zheng K, Lian M, Zhang C, et al. Longterm stabilization of $\mathrm{Cd}$ in agricultural soil using mercaptofunctionalized nano-silica (MPTS/nano-silica): a three-year field study. Ecotoxicol Environ Saf. 2020;197:110600.

74. Fang W, Shi X, Yang D, Hu X, Williams P, Shi B, et al. In situ selective measurement based on diffusive gradients in thin films technique with mercapto-functionalized mesoporous silica for high-resolution imaging of $\mathrm{Sb}(\mathrm{III})$ in soil. Anal Chem. 2020;92(5):3581-8.

75. Sharma R, Puri A, Kumar A, Monga Y, Gaba G, Adholeya A. Diacetylmonoxime functionalized silica gel: an efficient and recyclable organic inorganic hybrid material for selective removal of copper from fly ash ameliorated soil samples. Sep Sci Technol. 2014;49(5):709-20.

76. Grzesiak P, Łukaszyk J, Gabała E, Kurczewska J, Schroeder G. The influence of silica functionalized with silanes on migration of heavy metals in soil. Pol J Chem Technol. 2016;18(1):51-7.

77. Wang Y, Zhan W, Zheng K, Liu Y, Zou X, Zhang C, et al. Effect of surface-modified nano-silica on the mobility and fraction of $\mathrm{Cd}$ in contaminated agricultural soils. Soil Sediment Contam Int J. 2019;29(1):96-106.

78. Davison W. Diffusive gradients in thin-films for environmental measurements: Cambridge University Press; 2016.

79. Nriagu J, Becker C. Volcanic emissions of mercury to the atmosphere: global and regional inventories. Sci Total Environ. 2004;327(1-3):331-3.

80. Obrist D, Kirk J, Zhang L, Sunderland E, Jiskra M, Selin N. A review of global environmental mercury processes in response to human and natural perturbations: changes of emissions, climate, and land use. Ambio. 2018;47(2):116-40.

81. Risher J. Elemental mercury and inorganic mercury compounds. Geneva: World Health Organization; 2003.

82. Reis A, Davidson C, Vale C, Pereira E. Overview and challenges of mercury fractionation and speciation in soils. TrAC Trends Anal Chem. 2016;82:109-17.

83. Liu J, Feng X, Qiu G, Yao H, Shang L, Yan H. Intercomparison and applicability of some dynamic and equilibrium approaches to determine methylated mercury species in pore water. Environ Toxicol Chem. 2011;30(8):1739-44.

84. Cattani I, Spalla S, Beone G, Del Re A, Boccelli R, Trevisan M. Characterization of mercury species in soils by HPLC-ICP-MS and measurement of fraction removed by diffusive gradient in thin films. Talanta. 2008;74(5):1520-6.

85. Liu J, Feng X, Qiu G, Anderson C, Yao H. Prediction of methyl mercury uptake by rice plants (Oryza sativa L.) using the diffusive gradient in thin films technique. Environ Sci Technol. 2012;46(20):11013-20.

86. Buffle J. In situ monitoring of aquatic systems: chemical analysis and speciation: John Wiley \& Sons; 2001.

87. Ridošková A, Pelfrêne A, Douay F, Pelcová P, Smolíková V, Adam V. Bioavailability of mercury in contaminated soils assessed by the diffusive gradient in thin film technique in relation to uptake by miscanthus $\times$ giganteus. Environ Toxicol Chem. 2019;38(2):321-8.

88. Huu Nguyen V, Yee S, Hong Y, Moon D, Han S. Predicting mercury bioavailability in soil for earthworm eisenia fetida using the diffusive gradients in thin films technique. Environ Sci Pollut Res. 2019;26(19):19549-59. 
89. Docekalová H, Diviš P. Application of diffusive gradient in thin films technique (DGT) to measurement of mercury in aquatic systems. Talanta. 2005;65(5):1174-8.

90. Turull M, Fontàs C, Díez S. Diffusive gradient in thin films with open and restricted gels for predicting mercury uptake by plants. Environ Chem Lett. 2019;17(3):1353-8.

91. Bratkič A, Klun K, Gao Y. Mercury speciation in various aquatic systems using passive sampling technique of diffusive gradients in thin-film. Sci Total Environ. 2019;663:297-306.

92. Jain C, Ali I. Arsenic: occurrence, toxicity and speciation techniques. Water Res. 2000;34(17):4304-12.

93. Ferguson J, Gavis J. A review of the arsenic cycle in natural waters. Water Res. 1972;6(11):1259-74.

94. Su S, Zeng X, Bai L, Wang Y, Zhang L, Li M, Wu C. Concurrent methylation and demethylation of arsenic by fungi and their differential expression in the protoplasm proteome. Environ Pollut. 2017;225:620-7.

95. Bennett W, Teasdale P, Panther J, Welsh D, Zhao H, Jolley D. Investigating arsenic speciation and mobilization in sediments with DGT and DET: a mesocosm evaluation of oxic-anoxic transitions. Environ Sci Technol. 2012;46(7):3981-9.

96. Wang C, Yao Y, Wang P, Hou J, Qian J, Yuan Y, et al. In situ high-resolution evaluation of labile arsenic and mercury in sediment of a large shallow lake. Sci Total Environ. 2016;541:83-91.

97. Gorny J, Lesven L, Billon G, Dumoulin D, Noiriel C, Pirovano C, et al. Determination of total arsenic using a novel $\mathrm{Zn}$-ferrite binding gel for DGT techniques: application to the redox speciation of arsenic in river sediments. Talanta. 2015;144:890-8.

98. Bennett W, Teasdale P, Panther J, Welsh D, Jolley D. Speciation of dissolved inorganic arsenic by diffusive gradients in thin films: selective binding of As(III) by 3-mercaptopropyl-functionalized silica gel. Anal Chem. 2011;83(21):8293-9.

99. Gorny J, Dumoulin D, Alaimo V, Lesven L, Noiriel C, Madé B, et al. Passive sampler measurements of inorganic arsenic species in environmental waters: a comparison between 3-mercapto-silica, ferrihydrite, Metsorb ${ }^{\circledR}$, zinc ferrite, and zirconium dioxide binding gels. Talanta. 2019;198:518-26.

100. Garnier J, Garnier J, Jézéquel D, Angeletti B. Using DET and DGT probes (ferrihydrite and titanium dioxide) to investigate arsenic concentrations in soil porewater of an arsenic-contaminated paddy field in Bangladesh. Sci Total Environ. 2015;536:306-15.

101. Santner J, Larsen M, Kreuzeder A, Glud R. Two decades of chemical imaging of solutes in sediments and soils - a review. Anal Chim Acta. 2015;878:9-42.

102. Santner J, Williams P. Measurement at high spatial resolution. In W. Davison (Ed.), Diffusive gradients in thin-films for environmental measurements (Cambridge Environmental Chemistry
Series, pp. 174-215). Cambridge: Cambridge University Press. https://doi.org/10.1017/CBO9781316442654.009

103. Shi X, Fang W, Tang N, Williams P, Hu X, Liu Z, et al. In situ selective measurement of $\mathrm{Se}(\mathrm{IV})$ in waters and soils: diffusive gradients in thin-films with bi-functionalized silica nanoparticles. Environ Sci Technol. 2018;52(24):14140-8.

104. Yin D, Fang W, Guan D, Williams P, Moreno-Jimenez E, Gao Y, et al. Localized intensification of arsenic release within the emergent rice rhizosphere. Environ Sci Technol. 2020;54(6):3138-47.

105. Williams P, Santner J, Larsen M, Lehto N, Oburger E, Wenzel W, et al. Localized flux maxima of arsenic, lead, and iron around root apices in flooded lowland rice. Environ Sci Technol. 2014;48(15): 8498-506.

106. Cui J, Li Y, Jin Q, Li F. Silica nanoparticles inhibit arsenic uptake into rice suspension cells via improving pectin synthesis and the mechanical force of the cell wall. Environmental Science: Nano. 2020;7(1):162-71.

107. El-Naggar M, Abdelsalam N, Fouda M, Mackled M, Al-Jaddadi $\mathrm{M}$, Ali $\mathrm{H}$, et al. Soil application of nano silica on maize yield and its insecticidal activity against some stored insects after the postharvest. Nanomaterials. 2020;10(4):739.

108. Santos J, Barreto Â, Nogueira J, Daniel-da-Silva A, Trindade T, Amorim M, et al. Effects of amorphous silica nanopowders on the avoidance behavior of five soil species - a screening study. Nanomaterials. 2020;10(3):402.

109. Zhang X, Li J, Li D, Zhang H, Hu H. Silicon dioxide nanoparticles have contrasting effects on the temporal dynamics of sulfonamide and $\beta$-lactam resistance genes in soils amended with antibiotics. Environ Res Lett. 2020;15(3):034001.

110. Liu C, Xu N, Feng G, Zhou D, Cheng X, Li Z. Hydrochars and phosphate enhancing the transport of nanoparticle silica in saturated sands. Chemosphere. 2017;189:213-23.

111. Wang Y, Nowack B. Dynamic probabilistic material flow analysis of nano-SiO2, nano iron oxides, nano- $\mathrm{CeO}_{2}$, nano- $\mathrm{Al}_{2} \mathrm{O}_{3}$, and quantum dots in seven European regions. Environ Pollut. 2018;235:589-601.

112. Carey M, Meharg C, Williams P, et al. Global sourcing of lowinorganic arsenic rice grain. Exposure Health. 2019. https://doi. org/10.1007/s12403-019-00330-y.

113. Nguyen M. Worldwide bans of rice straw burning could increase human arsenic exposure. Environ Sci Technol. 2020;54(7):37289 .

Publisher's Note Springer Nature remains neutral with regard to jurisdictional claims in published maps and institutional affiliations. 